Print ISSN: 2252-0716 - Online ISSN: 2716-9855

\title{
The Effect of Club Social Responsibility on the Supportive Behavior of the Football Fans Brand: (Case Study of Persepolis Tehran Club)
}

\author{
Shahoo Zamani Dadaneh ${ }^{1}[\mathrm{D})$, Mohammad Reza Esmaili ${ }^{2}[\mathrm{D})^{*}$, Ali Zarei ${ }^{3}[\mathrm{ID}]$
}

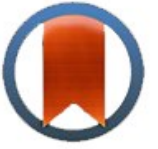

CrossMark

1. Shahoo Zamani Dadaneh, (PhD Student) Islamic Azad University, Central Tehran Branch, Tehran, Iran.

2. ${ }^{*}$ Mohammad Reza Esmaili, (Ph. D) Islamic Azad University, Central Tehran Branch, Tehran, Iran. moh.esmaili@iauctb.ac.ir

3. Ali Zarei, (Ph. D) Islamic Azad University, Central Tehran Branch, Tehran, Iran.

\section{ARTICLE INFO}

\section{Article type}

Research Article

\section{Article history}

Received August 2020

Revised January 2020

Accepted January 2020

\section{KEYWORDS:}

Relationship Marketing, Brand

Supportive Behavior, Social

Responsibility in Sports, Fan

Attitude, Empathy.

\section{CITE:}

Zamani Dadaneh, Esmaili, Zarei.

The Effect of Club Social

Responsibility on the Supportive

Behavior of the Football Fans

Brand: (Case Study of Persepolis

Tehran Club), Research in Sport

Management \& Motor Behavior,

2021: 11(22): 181-200

\section{ABSTRACT}

Nowadays, social responsibility is not limited to specific organization, and clubs and sports teams have included various forms of social responsibility in their goals and are involved in their implementation. The purpose of this study was to investigate the effect of club social responsibility on the supportive behavior of the brand of football fans with the mediating role of attitude: The moderator role was empathy. The method of the present study was descriptive-survey and was applied studies according to the purpose. In the present study, Persepolis Club as the study club and the statistical population of the present study consisted of all fans of Persepolis Club. 360 people were selected as the research sample and the available sampling method was used. Galbraith (2010) questionnaire was used to evaluate social responsibility, Zhi et al. (2019) questionnaire was used to support brand behaviors, and Zhi et al. (2019) questionnaire was used to measure attitude and empathy variables.To review and analyze of the data, descriptive and inferential statistics were used using the construction equation model, which used SPSS 25 and Smart PLS 3.2.9 software for experiments and analysis. The results showed that social responsibility had an effect on brand support behaviors and fan attitudes, also,the attitude of the fans on the supportive behaviors of the brand was influential and the mediating role of the fans' attitude regarding the impact of social responsibility on the supportive behaviors was confirmed. Finally, empathy plays a moderating role between the impacts of club social responsibility on fan supportive behaviors. 
تاثير مسئوليت اجتماعى باشعاه بر رفتار حمايتى از برند هواداران فوتبال:

\section{مطالعه موردى باشكاه بر سيوليس تهران}

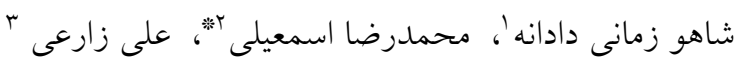

1 ا.دانشجوى دكترى، كروه مديريت ورزشى، واحد تهران مركزى، دانشخاه آزاد اسلامى، تهران، ايران.

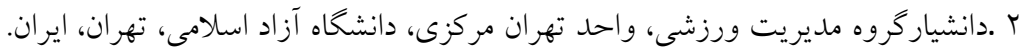

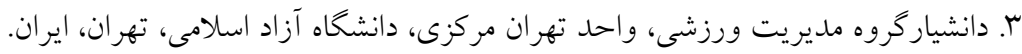

\begin{tabular}{|c|c|}
\hline 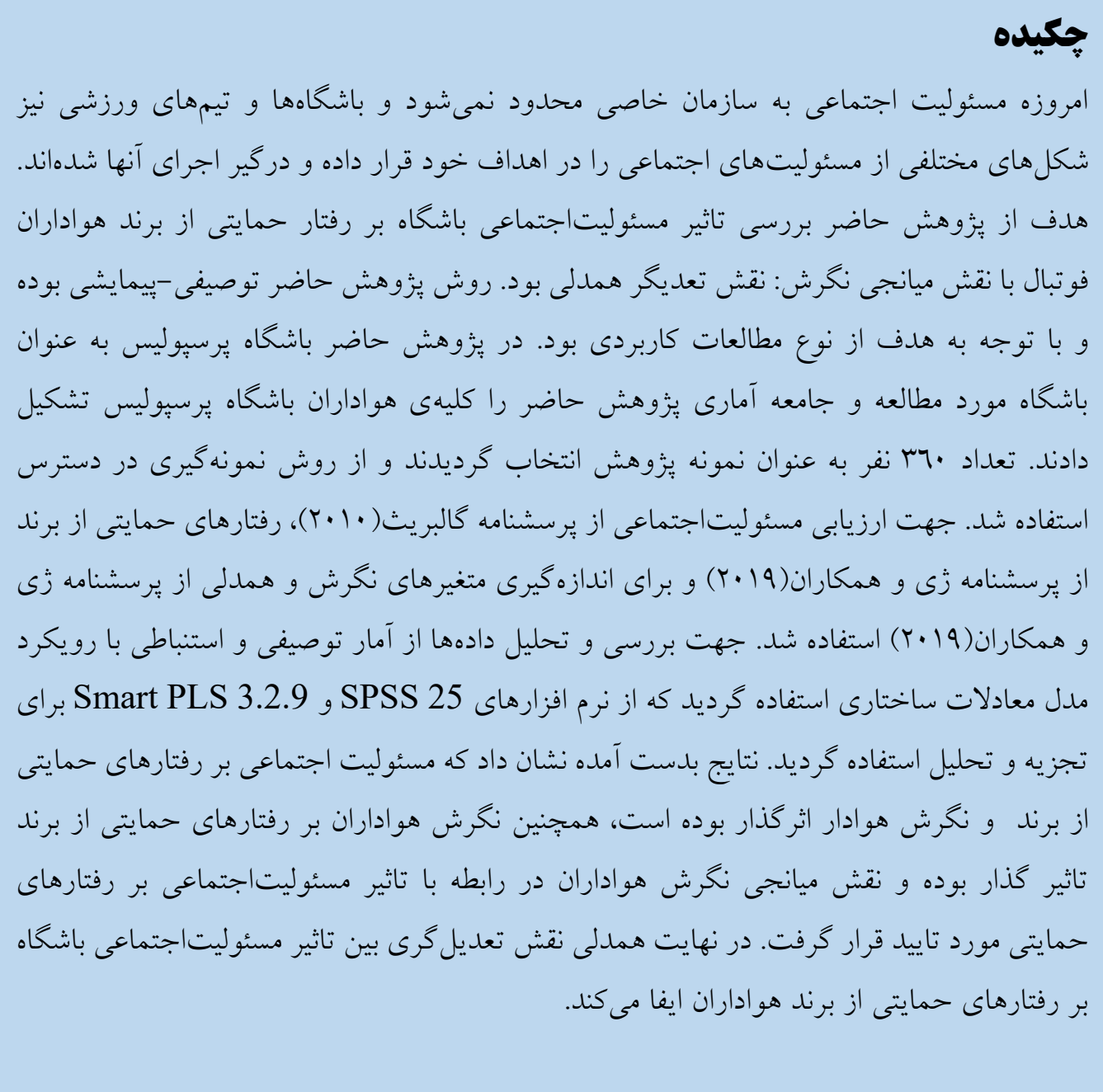 & 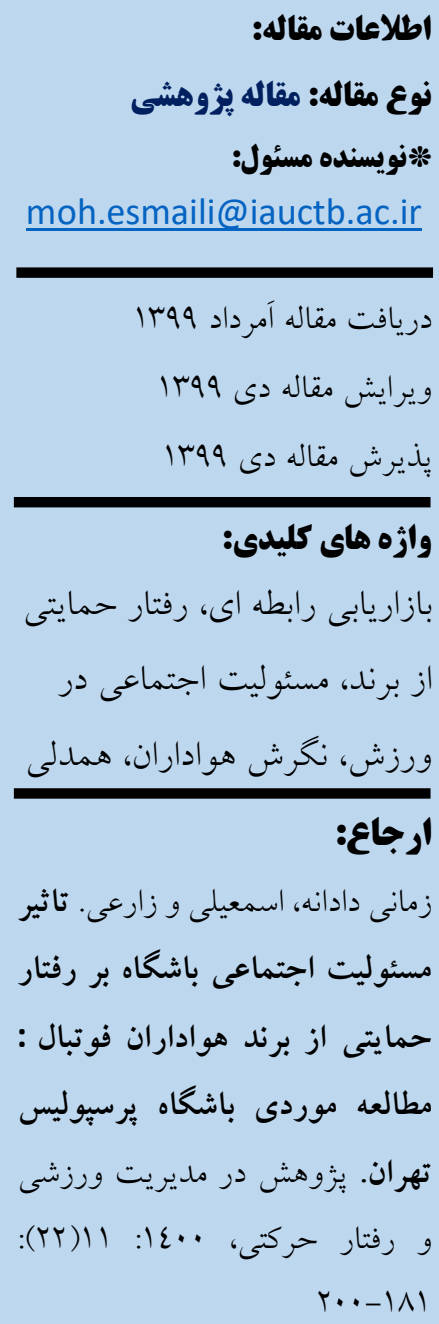 \\
\hline
\end{tabular}




\section{يخوهش در مديريت ورزشى و رفتار حركتى - دوره يازدهم ، شمارهبr، +.}

\section{مقلدمه}

امروزه سـازمانهـا در محيطى يويـا، جـــابهـام و متغيــر فعاليت مى كنند. اكنون در اقتصـاد جهـانى، مشـتريان بقـاى سـازمان را رقم مىزنند. شركتها ديخر نمىتوانند نسبت به انتظارات و خواستهاى مشتريان خود بى تغاوت باشند؛ جرا كه تنها منبع بركشت سرمايه، مشتريان هستند (Y). شرايط اقتصادى، محيط فيزيكى، مقررات دولتى و بيشرفتهاى تكنولوزيكى همكى بر نيازها و انتظارات مصرف كند كان و تو انايى هاى شركت و رقباى آن تأثير كذار هستند. سازمانها با فشار فزاينده ابقاء سودآورى از يك سو و رفتار به شيوههاى معقول جامعه از سوى ديخر مواجه هستند (YV) با توجه به به اين مطالب بازاريابى رابطهاى توجه فزايندهاى را از سوى فعالان حرفهاى و محافل آكادميك در سالهاى اخير به دست آورده است. تحقيقات اخير نشان مىدهد كه طرحهاى بازاريابى رابطهاى به طور فزايندهاى اصول اخلاقى و هويت اخلاقى بـ بـ را با مسئوليت اجتماعى شركت در هم آميخته است (YN). شركتها اغلب در تلاش هستند با اجرايى كردن مسئوليت يذيرى اجتماعى نفوذ خود در اجتماع، شهرت و ايستادكى كسب و كار خود را افزايش دهند. اقدامات مسئوليتيذيرى اجتماعى را مى توان به عنوان يك نوع رابطه اخلاقى در نظر كرفت، بنابراين براى مديران مهم است جخحونه كاركردهاى مسئوليتيذيرى اجتماعى شركتهايشان بر ارتباطات تجارى آنها تأثير مى كذارد( •ع). مسئوليت اجتماعى مفهومى است كه تاكيد مى كند سازمانها بايد علايق، خواستهها، سود و بهره عمومى جامعه را در اقدامات و تصميمات خود مورد توجه قرار دهند و آن را در تدوين برنامهها و اهداف سازمانى خود بخنجانند. اين ايده خاطر نشان مىكند، سازمانها مىتوانند به طور همزمان اهداف اجتماعى و محيطى را همانند كسب سود در نطر داشته باشند و به آنها دست يابند (Y). سولومون و همكاران (11 (Y)، در تعريفى از مسئوليت اجتماعى، عنوان مى كنند؛ مسئوليت اجتماعى شيوهاى از مديريت است كه طبق آن، سازمانها فعاليتهايى را انجام مىدهند كه اثر مثبتى بر جامعه و ترفيع كالاهاى عمومى داشته باشد (عَr). مسئوليتيذيرى اجتماعى به عنوان تعهلد شركتها يا برندها براى به حداكثر رساندن رفاه اقتصادى، اجتماعى و محيط زيست از طريق عملياتهاى كسبو كار، سياستها و منابع تعريف مىشود (Tr). زى و همكاران (19 (Y) معتقد هستند در بي كاركردهاى مسئوليت اجتماعى شركتها در مصرف كنند كان همدلى يديد مى آيد( •ع)، جرا كه مصرف كنند گان از طريق كاركردهاى مذبور سود دريافت مى كنند (דب). از طرفى تحقيقات زيادى در مورد اثرات مثبت اقدامات مسئوليت يذيرى اجتماعى بر نخرش مصرف كننده انجام شده است. مطالعات قبلى نشان مى دهند كه اقدامات مسئوليتيذيرى اجتماعى شركتها به نخرش مثبت در مصرف كننده منجر مىشود (Y9). نخرش به عنوان احساس مثبت يا منفى فرد در جريان يكى رفتار خاص تعريف مىشود (ع)) و شامل سه عنصر شناختى، احساسى و رفتارى است. منظور از جزء شناختى نخرش، اطلاعاتى است كه فرد دربارهى موضوع نخرش دارد، البته مهمترين اين شناختها آنهايى هستند كه با نوعى ارزيابى همراه باشند. عنصر احساسى نخرش نيز شامل احساسى است كه موضوع نخرش در شخص بر مى انخيزد، يعنى موضوع ممكن است خوشايند يا ناخوشايند باشد، ايجاد خوشى و خوشحالى كند يا بر انخيزندهاى نفرت و انزجار باشد (0). سرانجام منظور از عنصر رفتارى نوعى آمادكى براى عمل تعريف مىشود و در

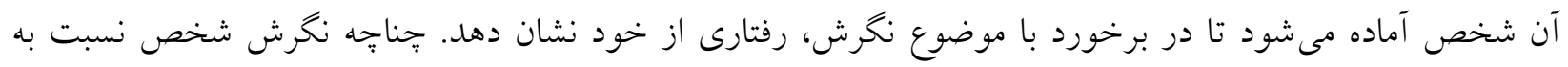




\section{بزوهش در مديريت ورزشى و رفتار حركتى - دوره يازهمر ، شمارهبr، +. ع|}

موضوعى مثبت باشد، آماده است كه كمك كند، ستايش كند، حمايت كند يا باداش دهد و برعكس اكر نخرش شخص

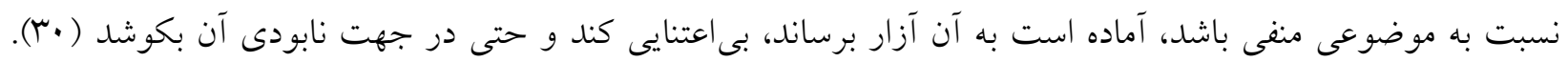

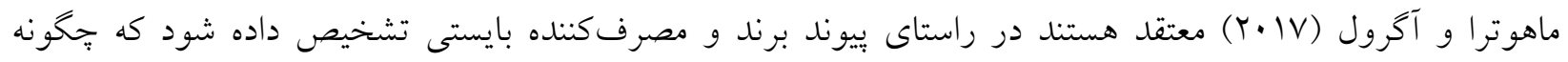
فعاليتهاى بازرايابى اخلاقى شركتها بر هويت اخلاقى مصرفكننده، هميوشانى برند، هيجانهاى اخلاقى، قضاوت

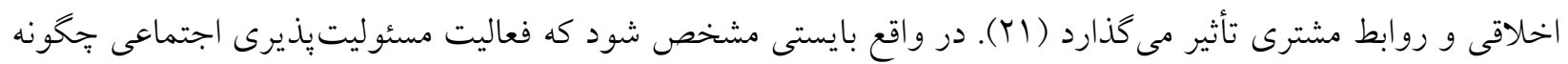
و جزه زمانى ارتباط مصرف كننده و برند را تحت تأثير خود قرار مىدهد كه منجر به رفتارى شود درنهايت حمايت منجر كردد. جرا كه مسئوليت اجتماعى در روابط مشترى و نام تجارى و در درى نخرشهاى برند مهم است كه حمايت هاى خود را از آن داشته باشند (IV). ورزش و تفريحات سالم دركشورهاى توسعهيافته به عنوان يك صنعت مهم و عامل اثر كذار در رشد اقتصاد ملى موردتوجه است و يكى از درآمدزاترين صنايع در قرن آبابه شمار ميرود كه با در اختيار داشتن عامل محركى همجيون مسابقات بزرگ ورزشى، امكان بهرهذيرى از فرصتهاى تبليغاتى و رسانها را فراهم نموده است كه اين موضوع بستر لازم براى تعامل مابين صنعت، تجارت و ورزش را سبب گرديده است (•r). باشخاههاى فوتبال نيز به منزلهى هستهى اصلى اين صنعت مانند بنخاه اقتصادى عمل مى كنند و با بهره كيرى از تجهيزات و امكانات، نيروى انسانى ماهر و متخصص و مديريت اثربخش، فوتبال را به صنعتى با كردش مالى زياد مبدل ساختهاند (1). به طوريكه، با افزايش سرمايه كذارى در ورزش حرفهاى، بهبود عملكرد ورزشى بيش از بيش مورد توجه قرار كرفته است. عملكرد تيمى و يو يايىهاى كروهى ورزشكاران، يكى از مسائل اصلى علوم ورزشى طى دهههاى كذشته بوده و شناسايى دلايلى كه تهرا برخى افراد و كروهها به موفقيت ميرسند، هدف مشترى ادبيات روانشناسى ورزشى است و البته مديريت ورزشى است (10). منظور از مسئوليت اجتماعى در ورزش، اين است كه تيمهاى ورزشى، تأثير فراوانى بر مسئوليتهاى اجتماعى

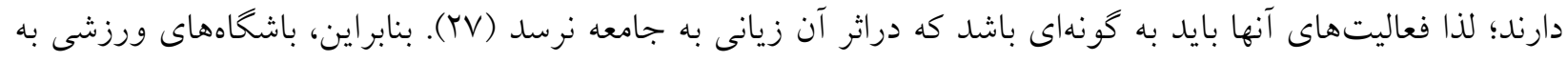
عنوان سازمانهاى ورزشى و متوليان ورزش در قبال تماشاگران و جامعه مسئوليتهايى تحت عنوان مسئوليت اجتماعى دارند و بايد توجه جدى به تأثير آن داشته باشند. باشخاههاى فوتبال از طريق انجام وظايف مسئوليت اجتماعى، حمايت طرفداران را افزايش مى دهند. زيرا يكى از راههاى باز گشت سرمايه كذارى براى باشخاهها، افزايش حمايت طرفداران است

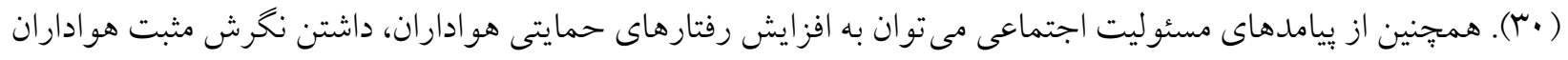
به باشخاهها از سوى هواداران و همدل و همراه بودن با باشخاه اشاره كرد. همدلى، متغيرى بيتخيده و جندبعدى است كه از نيمه اول قرن بيستم متفكران و نظريه يردازان علوم مختلف از جمله جامعه شناسى، روان شناسى و زيبا شناسى را به خود مشغول كرده است. بيش از سه دهه از زمانى كه راجرز نقش جديدى به عنوان عامل انخيزشى هواداران و دوست داران ورزش به تيم ها براى همدلى در نظر گرفته نمى گذرد. از آن زمان تا كنون تعداد زيادى از محققين سعى در ارائه روش ها و تكنيكهايى براى ايجاد همدلى بين هواداران و تيمها داشته اند (•ع). در اين رابطه زى و همكاران (19 •؟) در يزوهش خود بيان كردند مسئوليت اجتماعى و اخلاقى با بروز همدلى و نحرش مثبت مصرفكننده در ارتباط است. همجنين بر رفتار حمايت كننده مشترى از برند تاثير كذار است، همجنين در قسمتى ديخر از يُزوهش خود بيان كردند كه 


\section{بزوهش در مديريت ورزشى و رفتار حركتى - دوره يازهمر ، شمارهبr، +. ع|}

همدلى به عنوان يك تعديلخر مثبت باعث بيشتر شدن تاثير فعاليتهاى اجتماعى بر رفتارهاى حمايتى از برند شركت

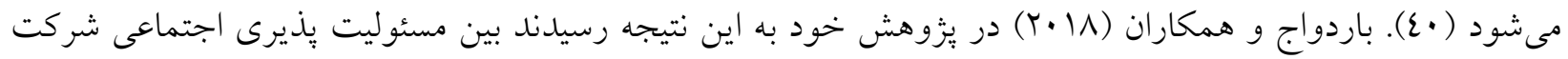
و حمايت از برند با آموزش و ابتكارات زيست محيطى رابطه مستقيم مثبت وجود داشت. اما بين ابتكارات محيطى و

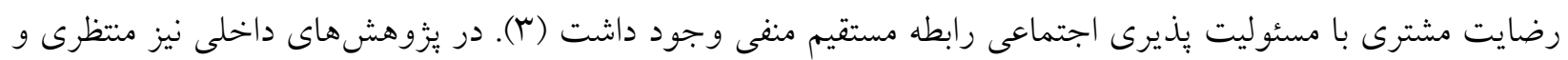
همكاران (1) (1) در يزوهشى با عنوان مدلسازى مسئوليت اجتماعى و نخرش هواداران نسبت به تيم در صنعت ورزش بيان كردند مسئوليت اجتماعى داراى اثرى مثبت هم به طور مستقيم و هم به طور غيرمستقيم بر ذهن و نخرش هو اداران است. از اين رو به مديريت تيمهاى ورزشى توصيه مىشود، علايق هواداران در مسائل و موضوعات اجتماعى را در نظر داشته و طرحهاى مختلف مسئوليت اجتماعى را در برنامه هاى بلند مدت خود قرار دهند (سY). بخشنده و همكاران

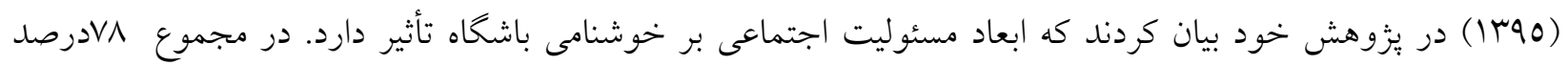

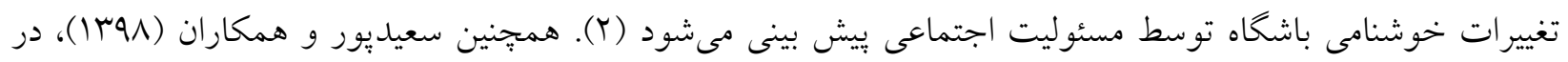
يُزوهشى با عنوان نقش مسئوليت اجتماعى بر عملكرد تيمى باشگاه برسبوليس با ميانجى گرى رضايتمندى هواداران انجام دادند كه يافتهاى برآمده از يُزوهش تأثير مستقيم و مثبت مسئوليت اجتماعى بر عملكرد تيمى و رضايتمندى هواداران و همجنين اثر كذارى مستقيم و مثبت رضايتمندى بر عملكرد تيمى را گزارش كردند. به علاوه، نقش جزئى ميانجى رضايتمندى در ارتباط مسئوليت اجتماعى و عملكرد تيمى مورد تأييد قرار گرفت (·r). به طور كلى زى و همكاران (19 (T) بر اين باور هستند كه اقدامات مسئوليت بذيرى اجتماعى با نخرش مثبت مصرف كننده در ارتباط است. اما اينكه مصرف كنند كان جهه ميزان از اين احساسات و نخرش را تجربه مى كنند بسته به تفاوتهاى فردى آنهاست. تفاوتهاى كه انظار مىرود مىتواند نقش تعديل گر را در ارتباط بين متغيرهاى مذبور بازى كند مشمول سطح

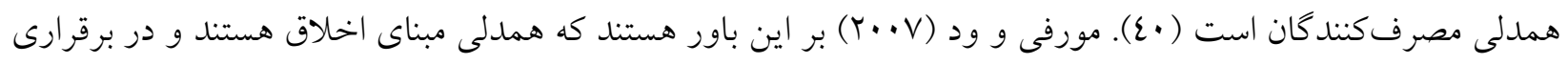
ارتباط نقش شاخصصهاى تسهيل كننده را بازى مى كنند (YT). در اين بين نشانكرهاى عدالت اجتماعى شامل عناصر برابرى در فرصتها، يذيرش شايستخى ها، احترام به كرامت انسانى و احترام به حقوق ديخران است. به زعم زى و همكاران (19.19) مصرف كنندگان با سطح عدالت اجتماعى بالاتر حساستر و در عين حال فضيليتهاى شركت را در بحث اخلاقيات بهتر درى مى كنند. جرا كه كاركردهاى مسئوليتيذيرى اجتماعى از برابرى فرصتها و احترام به حقوق ديخران حمايت مى كند. در مقابل همدلى شامل فهم و درى افكار و نخرش ديخران و انجام اقداماتى در جهت كمكى به آنها تعريف مى شود ( •ع)؛ و حداقل شامل دو نوع شناختى و عاطفى است (11). نوع شناختى فهم و درك افكار و احساسات ديخران با استفاده از منطق و تعقل خود و بدون همدردى با آنها رخ مى دهد و اين نوع همدلى غالباً با احساسات كمترى

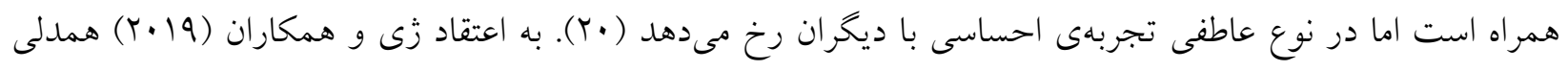
بالاتر با نخرش مثبت و حمايت در ارتباط است جرا كه همدلى متناسب با اخلاق جمعى است و اقدامات مسئوليتيذيرى اجتماعى تحت تأثير آن قرار مى گيرد. همجنين افرادى كه همدلى عاطفى بالاترى دارند نسبت به تلاشهاى انجامشده از 


\section{بزوهش در مديريت ورزشى و رفتار حركتى - دوره يازهمر ، شمارهبr، +. ع|}

سوى شركتها در قبال جامعه حساسيت بيشترى دارند و به احتمال زياد نوع نخرش آنها از اين طريق دستخوش تغيير شود (ع) (ع).

با توجه به نقش اجتماعى سازمانهاى ورزشى و به خصوص باشخاههاى فوتبال كه مخاطبين آن بخش وسيعى از جامعه مىباشد و همجنين از آنجا كه يك باشگاه فوتبال مى تواند تأثيرات اقتصادى، اخلاقى و انساندوستانه زيادى بر جامعه داشته باشد؛ كه اين مى تواند يك رابطه دوظرفه بين باشخاه و هواداران به وجود آورد. به عبارتى آيا انجام فعاليتهاى

مسئوليت اجتماعى متقابلا به باشخاه فوتبال منفعت ميرساند؟ در مورد مسئوليتهاى اجتماعى باشگاه فوتبال مىتوان كفت، با عنايت به اينكه تماشاگران سرمايههاى اصلى ورزشاند، باشخاهها مى بايست برنامه مشخص و جايخاه ويزهاى به كانونهاى هو ادارى و يا معاونتهاى فرهنكى باشگاه اختصاص دهند و در اين زمينه كلاسهاى آموزشى براى ليدرها و هواداران خود بر گزار و اخلاقمدارى و فرهنگ صحيح تماشاگرى را در بين طرفداران كسترش دهند. با توجه به اهميت كاركرد كانونهاى فوتبال مىتوان از باشخاههاى يرطرفدار مانند يرسبوليس كه در بالا توصيف شد الكو گرفت و در مسير توسعه خدمات باشخاهها در راستاى مسئوليت اجتماعى آنها حركت كرد (Y).با توجه به اينكه باشگاه يرسوِيس يكى از تيمهاى برطرفدار ايران و آسيا است و همواره در كانون توجهات قرار دارد و هواداران اين تيم و حتى هواداران تيمهاى ديخر به عنوان باشگاه رقيب فعل و انفعالات باشگاه

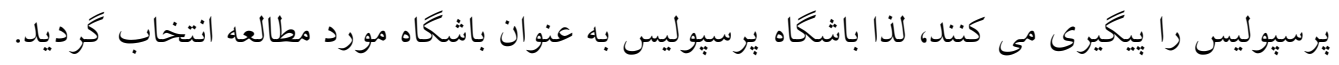
با توجه به مطالب ذكر شده مبنى بر كمبود تحقيقات انجام شده با موضوع مسئوليت اجتماعى در حيطه ورزش و سازمانهاى ورزشى از يكسو بنا به دلايل ذكر شده مسئوليت اجتماعى در حيطه ورزش از ديخر زمينهها متفاوت است و يافتهاى متفاوت در رابطه با تأثير مسئوليت اجتماعى بر نخرش و رفتار مصرف كنند كان از سوى ديخر، كروه تحقيق بر آن شد كه

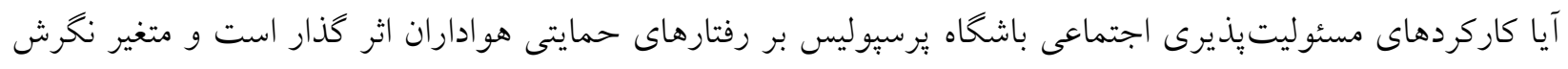
آيا نقش ميانجى را دارد و در نهايت متغير همدلى مىتواند نقش تعديلكر داشته باشد؟ كه مدل مفهومى آن به شكل زير ئري

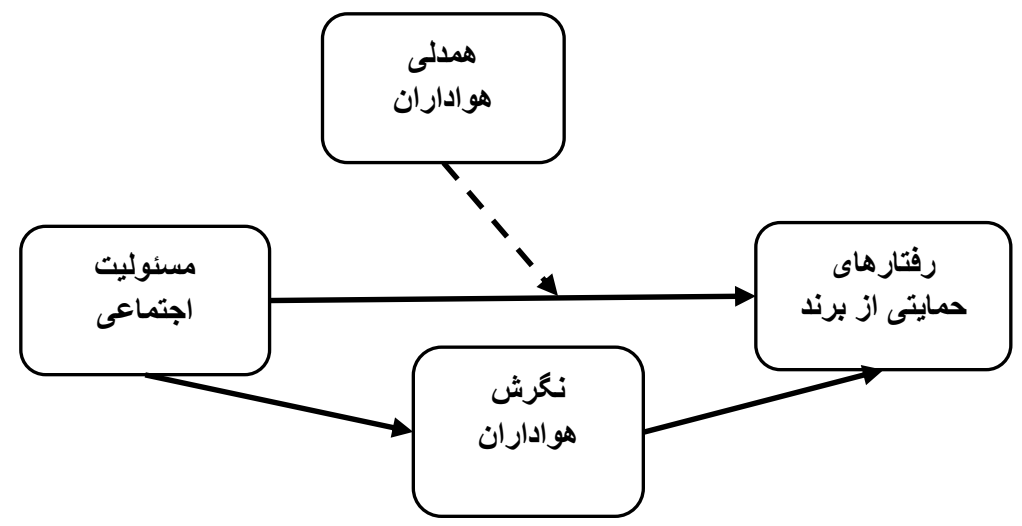

شكل ( (1: مدل مفهومى بروهش

https://jrsm.khu.ac.ir/ 


\section{بزوهش در مديريت ورزشى و رفتار حركتى - دوره يازهمر ، شمارهبr، +. ع|}

روش رشناسى يُوهش

روش يزوهش حاضر توصيفى -ييمايشى بوده و با توجه به هدف از نوع مطالعات كاربردى بود. در يزوهش حاضر باشخاه

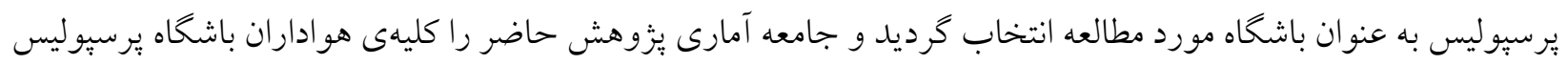
تشكيل دادند. هوادارانى كه حداقل يك بار در سال سابقه حضور در ورزشگاه محل بر گزارى مسابقات و يا تمرينات تيم

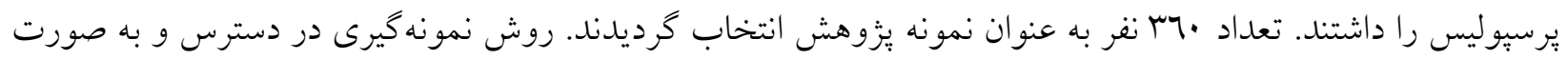
داوطلبانه انتخاب شدند. لازم به ذكر است كه يرسشنامهها به صورت الكترونيكى طراحى و در شبكههاى مجازى (تلكرام و اينستاكرام) مربوط به هو ادار ان برسبوليس توزيع گرديدند؛ به طورى كه هواداران نظر اتشان رادر قالب كويههاى طر احى شده (در مقياس ينج ارزشى ليكرت) و به صورت آنلاين براى محققين ارسال نمودند. با توجه به اهداف يزوهش ابزارهاى مناسب براى اين يزوهش يرسشنامه در نظر كرفته شد؛ بدين منظور به جهت ارزيابى مسئوليت اجتماعى از برسشنامه

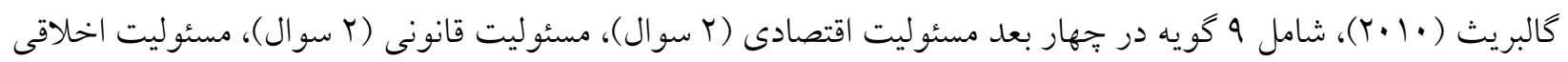

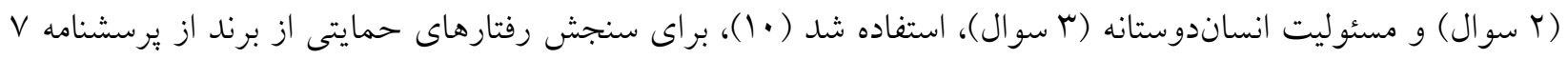
سؤالى زى و همكاران (19 (Y) كه حاوى ب بعد تبليغات شفاهى مثبت (r سؤال)، مقاومت كردن جهت ارائه ندادن اطلاعات

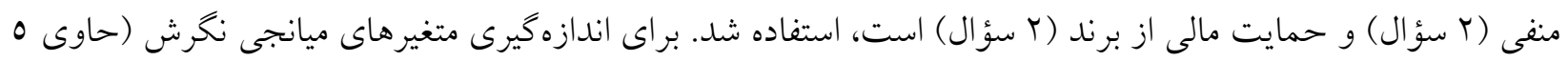

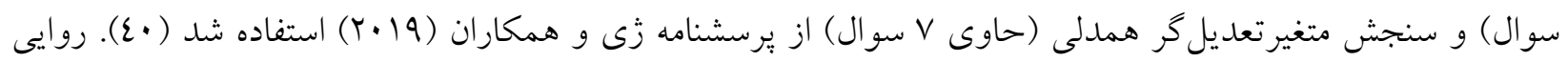
صورى و محتو ايى برسشنامهها يس از انجام ترجمه سه مرحلهاى به تأييد · انفر از صاحبنظران حيطه مديريت ورزشى ونى

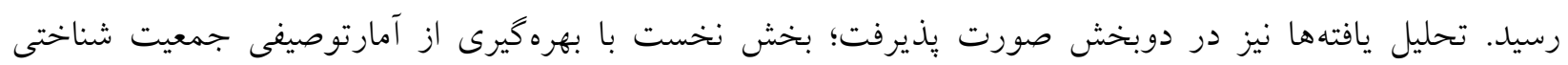

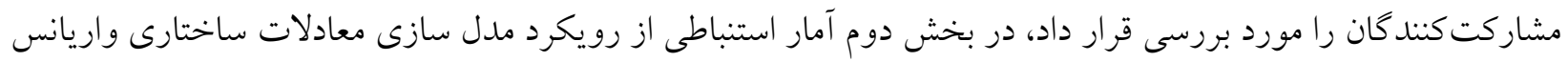
محور استفاده شد كه در دو بخش مدل بيرونى (مدل اندازه كيرى) و مدل درونى (مدل ساختارى) استفاده شد، كه از نرم افزارهاى SPSS 25 و Smart PLS 3.2.9 استفاده كرديد.

\section{يافته هاى تحقيق \\ يشفرضها}

به منظور اجراى مدلسازى معادله ساختارى واريانس محور توجه به بيشفرض إساسى اين رويكرد حائز اهميت است و بايستى بيش از اجراى مدل مورد بررسى قرار كيرد. يكى از اين بيشفرض ها حجم بهينه نمونه است. مولر (1999) براى تعيين حجم نمونه از نسبت حجم نمونه به بار آمتر آزاد براى بر آورد استفاده مى كند. وى حداقل اين نسئ نسبت راه

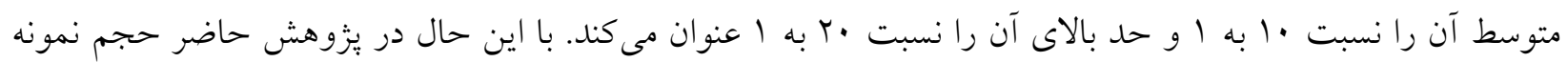
• جr نفر به منظور اجراى مدلسازى معادله ساختارى كفايت لازم را دارد (Yo). دومين بيش فرض همخطى جند كانه است، اكر همخطى در يك معادله رگرسيون بالا باشد بدين معنى است كه بين متغيرها مستقل همبستكى بالايى وجود دارد و اعتبار مدل زير سوال مىرود. در يزوهش حاضر به منظور بررسى همخطى بين متغيرهاى مستقل در مدلها معادله ساختارى 


\section{يزوهش در مديريت ورزشى و رفتار حركتى - دوره يازدهم ، شماره r؟، +.ع|}

از مقادير مربوط به دو شاخص تورم واريانس ا و تحمل Y كه نشان دهنده ميزان همخطى بين متغيرهاى مستقل مىباشند استفاده كرديده است

\begin{tabular}{|c|c|c|}
\hline \multicolumn{2}{|c|}{ شاخص هاى همخطى جند گانه } & \multirow{2}{*}{ متغير ها } \\
\hline عامل تورم واريانس & شاخص تحمل & \\
\hline $1 / 7 \wedge \varepsilon$ & $\cdot / 01 \mathrm{~V}$ & مسئوليت اجتماعى \\
\hline I/NEr & $\cdot / 0 \varepsilon \mathrm{V}$ & نخرش هواداران \\
\hline$r / \cdot 11$ &.$/ 0 Y r$ & همدلى \\
\hline
\end{tabular}

با مدنظر قرار دادن نقطه برش مربوط به شاخصهاى تحمل و عامل تورم واريانس كه به ترتيب ع/ • و ب/ مع باشد (بيشتر از ع/• بودن شاخص تحمل و كمتر از T/0 بودن عامل تورم واريانس) نتايج اين دو شاخص در يزوهش حاضر بيانخر عدم وجود همخطى جند كانه و يا به عبارتى مطلوبيت اين بيش فرض است. سومين بيش فرض در اين رابطه مقدار باقيماندههاى استاندارد است، با استفاده از اين شاخص موارد دور افتاده و يا برت (موارد دور افتاده مواردى هستند كه الخوى رابطه متغيرهاىشان با ساير افراد به شدت متفاوت است، اينها كسانى هستند كه معادله ركرسيون وقتى كه مقدار متغير وابسته آنها را بيشبينى مى كند، بيشبينىاش از واقعيت اين افراد خيلى دور خواهد بود و زمانى كه بيشبينى از واقعيت اين موارد دور باشد باعث آن مىشود كه نمره باقيمانده بزرى شود) مشخص مى گردد.

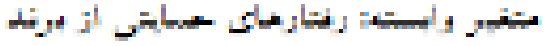

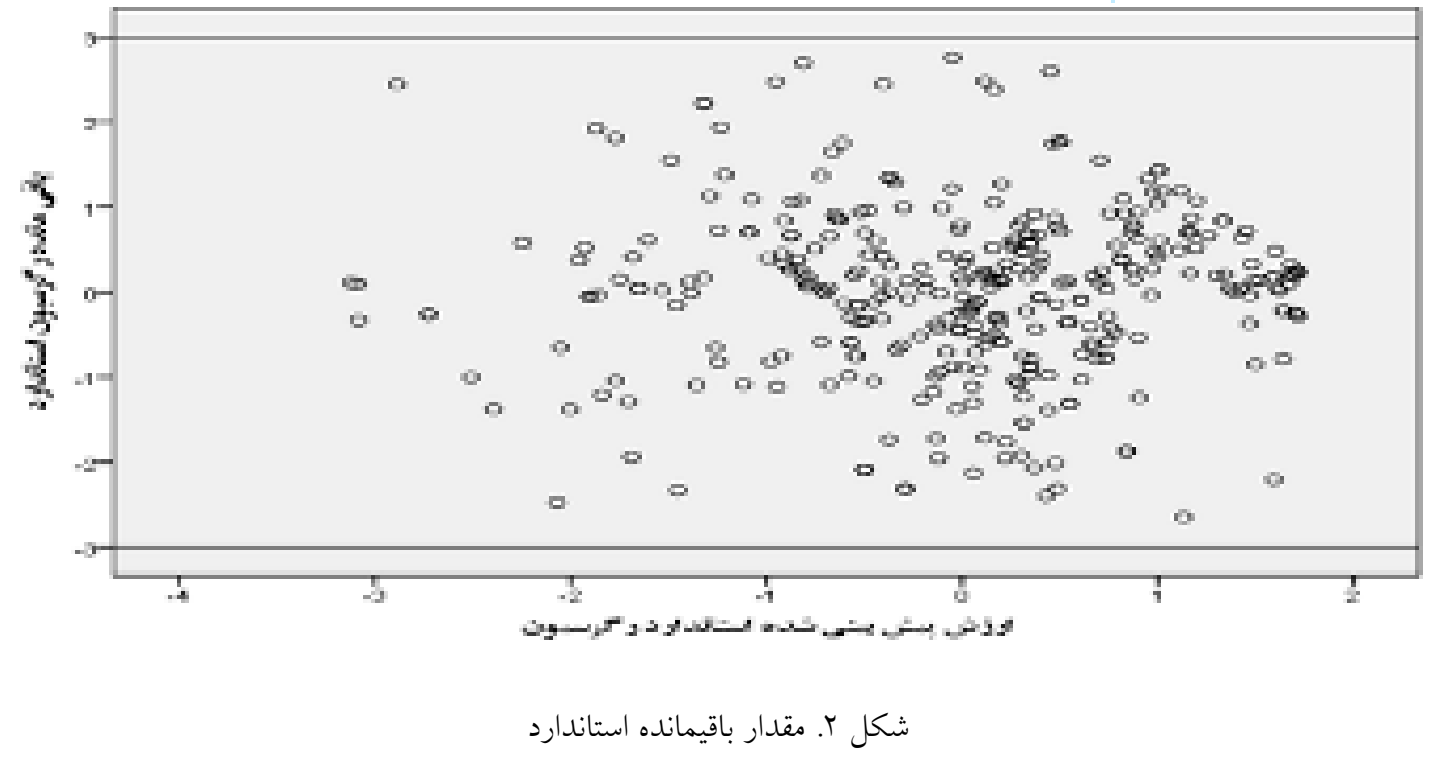

1 VIF

2 Tolerance

https://jrsm.khu.ac.ir/ 


\section{بزوهش در مديريت ورزشى و رفتار حركتى - دوره يازهمر ، شمارهبr، +. ع|}

مرزى كه مشخص شد براى اينكه يك مورد يرت قلمداد شود اين است كه نمره باقيمانده استاندارد او در دامنه ب- تا س

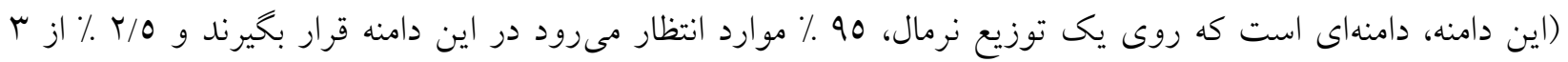

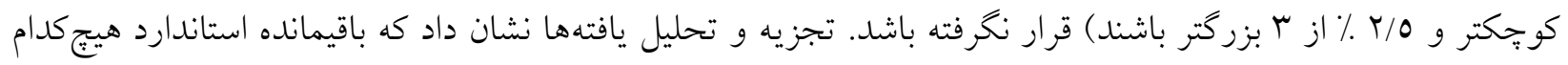
از موردها خارج از مرز تعيين شده نيست و در نهايت آخرين بيشفرض دادههاى يرت جندمتغيره است، دادههاى يرت

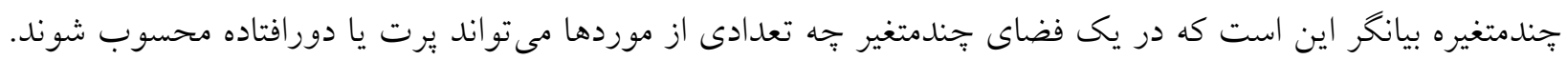
در اين يزوهش نيز به منظور تشخيص دادههاى يرت جنندمتغيره مورد استناد قرار گرفته است شاخص فاصله ماهالونوبيس است. در اين يزٔوهش جون ץ متغير مستقل وجود داشت درجهآزادى برابر با ץ بود. مقدار مجذور كاى متناظر با درجه

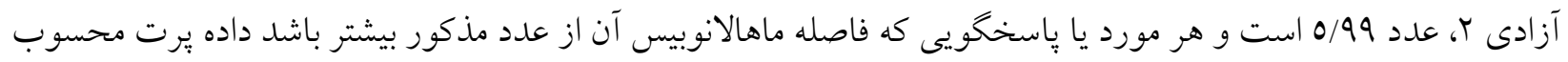

مىشود (V) ( D)

جدول r. برآورد دادههاى يرت جندمتغيره با استفاده از فاصله ماهالانوبيس

\begin{tabular}{|c|c|c|c|}
\hline \multicolumn{3}{|c|}{ فاصله ماهالانوبيس } & \\
\hline حداكثر مقدار & حداقل مقدار & تعداد & \\
\hline $0 / N r$ & $\cdot \cdots \vee \wedge$ & rา. & موارد \\
\hline
\end{tabular}

با استناد به اين نتايج حاصل شده مشخص مى گردد كه دادهاى يرت جندمتغيره در مجموع دادهاى اين يزوهش وجود ندارد. با تأييد ييش فرض هاى آزمون مدل سازى معادله ساختارى، استفاده از اين رويكرد بلامانع است. يافته هاى تحقيق در بخش اطلاعات توصيفى متغيرهاى جمعيت شناختى به شرح زير بود:

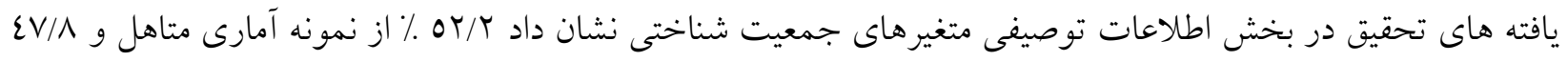

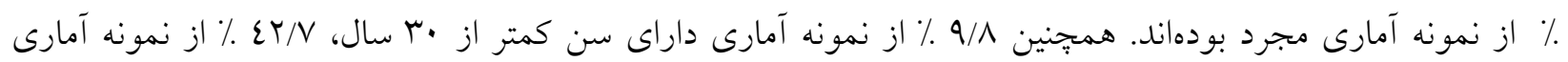

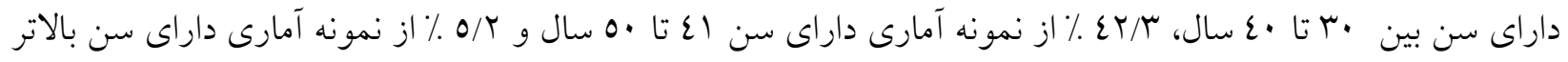

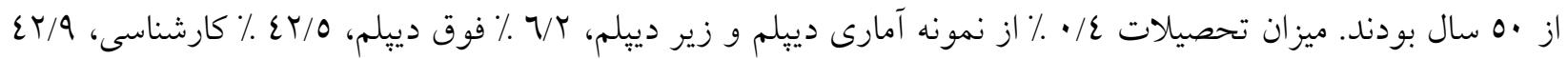

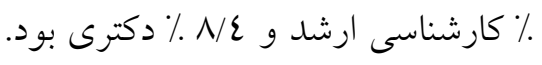

\section{تحليل عاملى تاييدى}

تجزيه و تحليل يافتهاى تحقيق با استفاده از مدل سازى معادله ساختارى رويكرد واريانس محور انجام كرديد (ع). مدل يابى بي ال اس در دو مرحله صورت مىيذيرد. در مرحلهُ اول، مدل اندازهيرى (مدل بيرونى) از طريق تحليل هاى روايى و پايايى و تحليل عاملى تأييدى بررسى مىشود و در مرحلةُ دوم، مدل ساختارى (مدل درونى) با بر آورد مسير بين متغيرها مورد ارزيابى قرار مى گيرد. 
جدول r- شاخصهاى ارزيابى مدل اندازهيرى

\begin{tabular}{|c|c|c|c|}
\hline$\lambda$ & $\mathbf{T}$ & كويه ها & متغير \\
\hline \multicolumn{3}{|c|}{$\mathbf{A V E}=\cdot /$ orr } & شاخص \\
\hline$\cdot / 77 \mathrm{~V}$ & I I I & باشگاه يرسيوليس با احترام به قوانين و مقررات، قراردادهاى شفاف مىبندد & \multirow{5}{*}{ 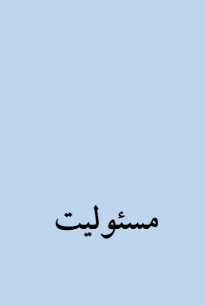 } \\
\hline$\cdot N \backslash 1$ & $11 / 479$ & اين باشخاه نخران ايمنى طرفداران و هواداران خود است & \\
\hline$\cdot / 7 \Lambda \Lambda$ & IV/TY. & سودآورى و رشد اقتصادى براى باشخاه برسيوليس مهم است & \\
\hline - / \£O & $1 \varepsilon / V 70$ & اين باشخاه با اسيانسرهاى قوى قرارداد مىبيندد & \\
\hline$\cdot / \mathrm{VV}$. & $10 / Y 1 \varepsilon$ & باشگاه يرسيوليس به اصول اخلاقى يايبند است & \\
\hline$\cdot / 7 \cdot 7$ & $1 \varepsilon / \varepsilon \vee q$ & اين باشگاه در راه ترويج اصول اخلاقى گام برمىدارد & \multirow[t]{4}{*}{ اجتماعى } \\
\hline - /Tro & $1 Y / \wedge 97$ & براى باشگاه برسيوليس فعاليتهاى انساندوستانه مهم مى باشد & \\
\hline - /UN & $18 / 19$. & اين باشگاه در فعاليتهاى با اهداف خيريه مشاركت مىنمايد & \\
\hline.$/ 710$ & $1 \% / \varepsilon \cdot 0$ & اين باشخاه به نيازمندان كمكهاى مالى مى كند & \\
\hline \multicolumn{3}{|c|}{$\mathbf{A V E}=\cdot / 071$} & شاخد \\
\hline$\cdot / T \Lambda \mu$ & $1 \varepsilon / \wedge \wedge q$ & تيم محبوبم بهترين تيم در ليخ است & \multirow{5}{*}{ 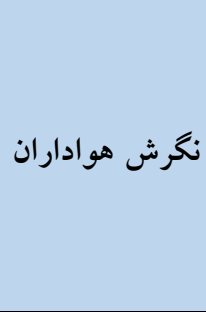 } \\
\hline$\cdot / 219$ & $r M / T r \varepsilon$ & من هميشه تيم محبوبم را دوست دارم حتى اخر شكست بخورد & \\
\hline . /79r & $\mid 7 / 201$ & من هميشه به اخبار مرتبط با تيم محبوبم علاقهمند هستم. & \\
\hline •NIT & IN/OET & من براى خريد بليت بازىهاى تيم محبوبم در طول وصل تمايل دارم & \\
\hline$\cdot / 7 \cdot 1$ & $|r / 9 T|$ & من اطلاعات مربوط به تيم محبوبم را از منابع اطلاعاتى گوناگونى كسب مىكنم & \\
\hline \multicolumn{3}{|c|}{$\mathbf{A V E}=\cdot / 0 \mathrm{~V}$} & شاخص ها \\
\hline.$/ 7 T_{0}$ & IV/ITV & در زمان باخت و برد همراه تيمم هستم & \multirow{7}{*}{ 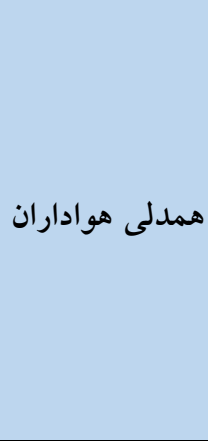 } \\
\hline.$/ 790$ & $19 / \wedge r q$ & من در فعاليتهاى كه تيم محبوبم حمايت از آن حمايت مى كند، شر كت مى كنم & \\
\hline . /79r & $r \mu / I V q$ & تغييراتى كه بر تيم محبوبم تأثير مى گذارد، بر زندگى شخصى من نيز تأثير گذارخواهند بود & \\
\hline •NMN & TO/HTH & من همراه با ساير هواداران در فعاليت هاى باشگاه تيم محبوبم شركت مى كنم & \\
\hline - Nor & $\mathrm{TV} / 770$ & تغييراتى كه بر تيم محبوبم تأثير مى گذارد، بر زندگى شخصى من نيز تأثير كذار خواهند بود & \\
\hline$\cdot / N \cdot 7$ & $r Y / \cdot \wedge$. & من با تعداد زيادى از هوادارن تيم محبوبم در ارتباط هستم & \\
\hline.$/ 0 \mathrm{~V}$ & $\mid 1 / \varepsilon r \Lambda$ & من از اتفاقات داخل و خارج تيم محبوبم خبر دارم و تيم محبوبم را حمايت مىكنم & \\
\hline \multicolumn{3}{|c|}{$\mathbf{A V E}=\cdot /$ or^ } & شاخص ها \\
\hline דוד/ • & $1 V / 177$ & در هر شرايطى از اين برند (برند باشگاه) حمايت مىكنم & \multirow{7}{*}{ حمايتى برند } \\
\hline .1097 & $1 \% / 70$. & من براى اين برند (برند باشخاه) در جامعه تبليخ مىكنم & \\
\hline$\cdot N \mu \wedge$ & TV/ITO & اولويت اول من تهيه محصولات اين برند(محصولات باشخاه) است & \\
\hline$\cdot / 7 \mathrm{~V}$ & $\mid N / \varepsilon \wedge r$ & معمولا قسمتى از درآمدم را به اين برند (برند باشگاه) اختصاص مىدهم & \\
\hline$\cdot N \cdot V$ & $r T / 1 T \varepsilon$ & اين باشگاه و خدماتاش را در هر زمان، مكان و به هر كسى كه بذيراى صحبت من باشد، سفارش مى كنم. & \\
\hline$\cdot / 7 \cdot 9$ & $1 r / .0 r$ & حاضر زمان زيادى را بخذارم تا جيزهاى مثبت و خوب درباه اين باشخاه را به ديخران بخوييم. & \\
\hline$\cdot / 7 \cdot 1$ & $\mid r / \varepsilon r$. & برند (باشگاه) مى تواند از ما به عنوان يك مشترى مرجع استفاده كند. & \\
\hline
\end{tabular}




\section{بزوهش در مديريت ورزشى و رفتار حركتى - دوره يازهمر ، شمارهبr، +. ع|}

بار عاملى مقدار عددى است كه ميزان شدت رابطه ميان يك متغير ينهان (سازه) و متغير آشكار (شاخص) مربوطه راطى كا فرآيند تحليل مسير مشخص مى كند. هر جهه مقدار بار عاملى يك شاخص در رابطه با يك سازه مشخص بيشتر باشد، آن شاخص سهم بيشترى در تبيين آن سازه ايفا مى كند (7). اخر بار عاملى كمتر ஈ/ • باشد ضعيف است و از آن صرف نظر

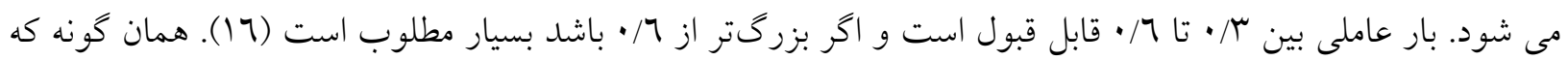
در جدول شمارهُ سه مشاهده مىشود، در مدل يزوهش، تمامى اعداد ضرايب بارهاى عاملى يرسشها بيشتر از (0/•)

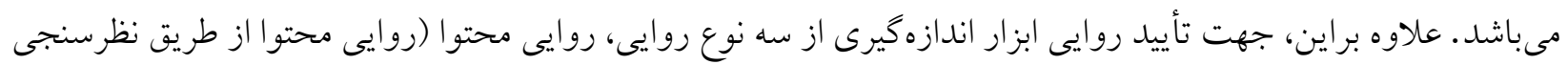
از خبر گان مورد تأييد قرار گرفت)، روايى همخراّ"و روايى واخرا استفاده شده است. به منظور تعيين بايايى برسشنامه نيز از دو معيار ضريب آلفاى كرونباخ و ضريب پيايايى مركب استفاده شد. مقدار ملاك براى مناسب بودن آلفاى كرونباخ بالاى

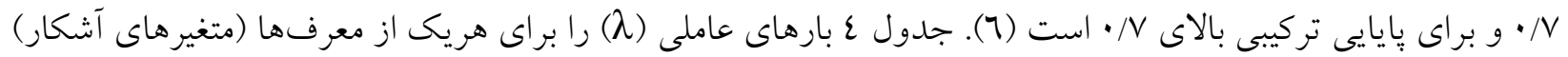

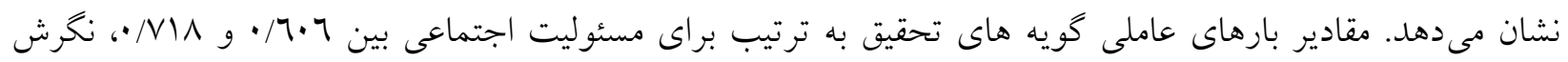

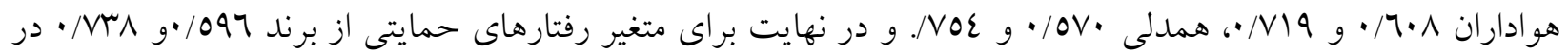
نوسان است كه نشان مىدهد اين مقادير بالاتر از آستانه (مقدار قابل انتظار) ب/ • قرار دارند. براين اساس، اعتيار همخر ايى در متغيرهاى مذبور برقرار است. همجنين مقادير آلفاى كرونباخ و بايايى نيز از مقدار ييشنهادى V/ • بزر گتر بودند به علاوه تمامى مقادير ميانخين واريانس استخراج شده بالاى استاندارد بيشنهادى بود و از مقدار حداقلى • 0 • تخطى كردند. براين اساس مىتوان كفت كه مدل اندازه گيرى تحليل عاملى تاييدى متغيرهاى يزوهش از برازش قابل قبولى دارد (ع ().

مدل اندازهيرى

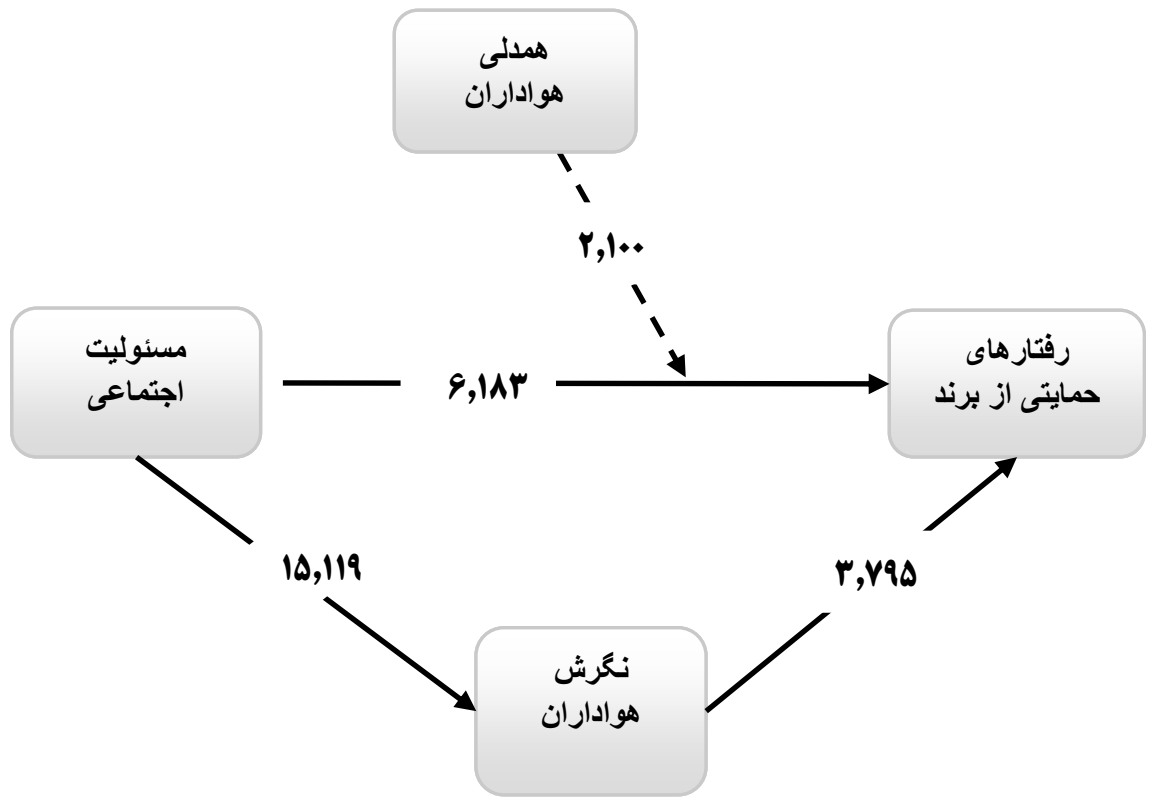

${ }^{3} \mathrm{AVE}$

https://jrsm.khu.ac.ir/ 


\section{يخوهش در مديريت ورزشى و رفتار حركتى - دوره يازدهم ، شمارهبr، +.}

شكل r. مدل معادلات ساختارى تحقيق در حالت استاندارد

با توجه به شكل بالا، تمامى ضرايب معنادارى Z از 1/97 بيشتر هستند كه اين امر معنادار بودن تمامى سوالات و مولفهها و روابط ميان متغيرها را در سطح اطمينان 90/ • نشان مى دهد.

جدول ع. ماتريس جدول روايى واگرا به روش فورنل و لاركر

\begin{tabular}{|c|c|c|c|c|}
\hline نخرش هواداران & مسئوليت اجتماعى & حمايتى از برند & همدلى & متغيرها \\
\hline - & - & - & - $/ A Y \mid$ & همدلى \\
\hline- & - & . /AYT & . VIT & رفتارهاى حمايتى از برند \\
\hline- & - /AYT & - NYT &.$/ 7 V \varepsilon$ & مسئوليت اجتماعى \\
\hline 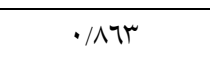 &.$/ 7 \vee 7$ & $\cdot / N \cdot 9$ & $\cdot / \wedge 1$ & نكرش هواداران \\
\hline
\end{tabular}

مطابق با ماتريس آورده شده در جدول 0، مقادير قطر اصلى تمامى احساسات اخلاقى مثبت، رفتارهاى حمايتى از برند، مسئوليت اجتماعى و نخرش هواداران از مقدار همبستخى آن با ساير سازهها بيشتر است كه اين امر روايى واخراى مناسب و برازش خوب مدل اندازه گيرى را نشان مى دهد. مقدار اساسى ارزيابى متغيرهاى مكنون درون زا، ضريب تعيين مىباشد. اين شاخص نشان مىدهد جند درصد از تغييرات متغير درونزا توسط متغير برونزا صورت مىيذيرد و اين مقدار براى

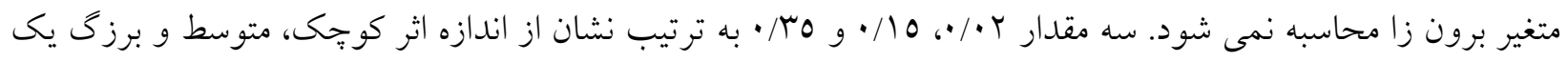
سازه بر سازه ديخر دارد (9).

جدول 0. ميزان ضريب تعيين متغيرهاى درون زا

\begin{tabular}{|c|c|}
\hline ضريب تعيين (R2) & متغير \\
\hline$\cdot / 21 \wedge$ & رفتارهاى حمايتى از برند \\
\hline$\cdot \pi / \mu$ & نخرش هواداران \\
\hline
\end{tabular}

مقادير ضريب تعيين مربوط به متغيرهاى رفتارهاى حمايتى از برند و نخرش هواداران به ترتيب برابر است با / |ح/ • و ץی//• كه مقدار ضريب تعيين مربوط به متغير درونزاى رفتارهاى حمايتى از برند اندازه اثر بزرگ و مقدار ضريب تعيين مربوط به متغير نخرش هواداران اندازه اثر متوسط متغير برون زا بر متغير درون زا را نشان مىدهد و نشان از برازش مناسب مدل ساختارى مدل است.

جدول 7. شاخص هاى كيفيت و برازش مدل

\begin{tabular}{|c|c|c|c|}
\hline SRMR & GOF & Q2 & متغير \\
\hline \multirow{2}{*}{$\cdot / \cdot v 7$} & \multirow{2}{*}{$\cdot \pi 97$} & $\cdot / \varepsilon \wedge \varepsilon$ & رفتارهاى حمايتى از برند \\
\hline & & $\cdot \mu \cdot r$ & نيخرش هو اداران \\
\hline
\end{tabular}




\section{بزوهش در مديريت ورزشى و رفتار حركتى - دوره يازدهم ، شمارهبr، +. E1}

معروفترين و شناخته ترين معيار اندازه كيرى اين توانايى شاخص Q2 استون - كايسلر است كه بر اساس اين ملاك مدل بايد نشانخرهاى متغيرهاى مكنون درون زاى انعكاسى را بيش بينى كند. مقادير Q2 بالاى صفر نشان مىدهد كه

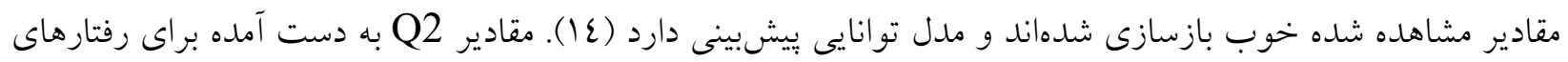

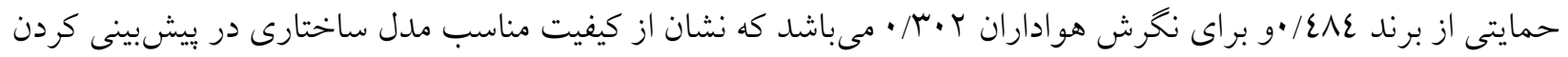
دارد. شاخص نيكويى برازش نيز معيار مربوط به سنجش كلى مدلهاى معادلات ساختارى است. بدين معنى كه توسط اين

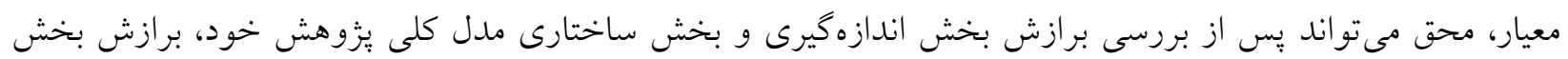

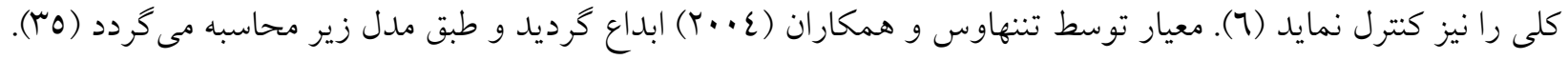

\section{GoF $=\sqrt{ }$ Communalities $\times R 2$}

اين شاخص، مجذور مقدار ضرب ميانخين مقادير اشتراكى و ميانخين ضريب تعيين است. وتزلس و همكاران (9.9. سه

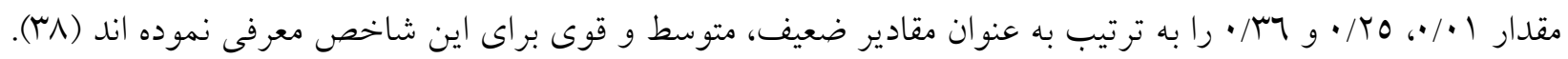
با توجه به مقدار 077/، معيار شاخص نيكويى برازش نشان از برازش كلى قوى مدل را دارد. در نهايت هير و همكاران (Y.17) جهت ارزيابى كلى مدل، معيارى را تحت عنوان شاخص اصلى نيكويى برازاش در مدل سازى معادلات ساختارى در رويكرد واريانس محور معرفى كردند كه در اصلاح به ريشه ميانخين مربعات باقيمانده استاندارد شده (SRMR) مرسوم است، كه نقطه برش در اين شاخص كمتر از ^•/• در نظر گرفته شده است؛ كه در اين بزوهش اين نقطه برش نيز رعايت شد (r) ).

به عبارت ديخر برازش دادهها به مدل برقرار است و همكى شاخصها دلالت بر مطلوبيت مدل معادله ساختارى دارند.

\section{مدل ساختارى}

نتايج مدل معادله ساختارى فرضارى مهاى تدوين شده اين يزوهش را حمايت كرد. شكل r مدل معادله ساختارى تحقيق را در حالت معنادارى نشان مىدهد و جدول شماره 0 مجموع اثرات بين متغيرهاى ينهان تحقيق را نشان مىدهد. 


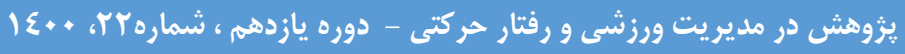

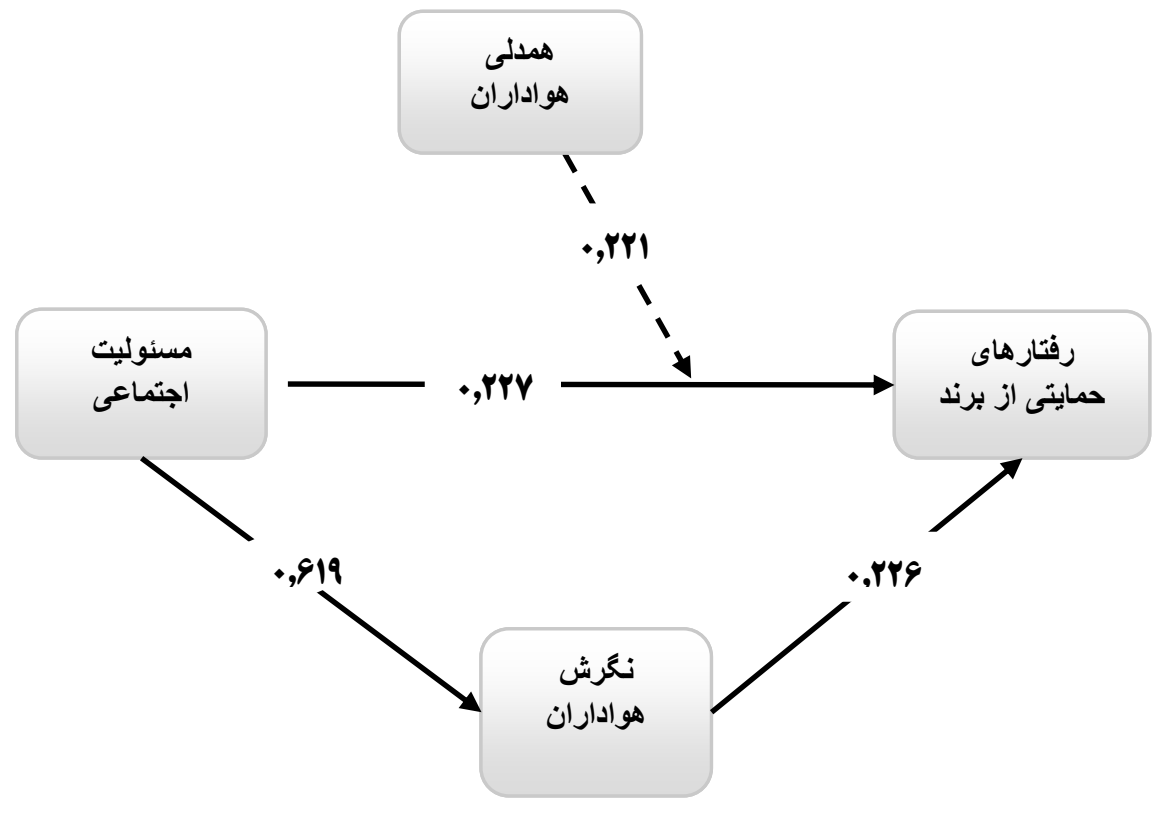

شكل r. مدل معادلات ساختارى تحقيق در حالت معنادارى

جدول V. مجموع اثرات مستقيم بين متغير هاى بنهان

\begin{tabular}{|c|c|c|c|}
\hline 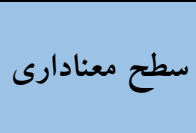 & $\mathbf{t}$ & 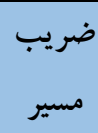 & مسير \\
\hline$\cdot / \cdot 1$ & $10 / 119$ & $\cdot / 719$ & مسئوليت اجتماعى --->نخرش هواداران \\
\hline$\cdot / \cdot 1$ & $\mathrm{~T} / \wedge \mathrm{r}$ & $\cdot / T Y V$ & مسئوليت اجتماعى --->رفتارهاى حمايتى از برند \\
\hline$\cdot / \cdot r$ & r/v90 & $\cdot / r Y 7$ & نغرش هواداران --->رفتارهاى حمايتى از برند \\
\hline$\cdot / \cdot 1$ & $r / 0 \wedge \mathrm{V}$ & $\cdot / \Omega \varepsilon$. & مسئوليت اجتماعى ---> احساسات اخلاقى مثبت ---> رفتارهاى حمايتى از \\
\hline$\cdot / \cdot 1$ & $r / 1 \cdot$. & $\cdot / T Y I$ & مسئوليت اجتماعى Xهمدلى هواداران ---> رفتارهاى حمايتى از برند \\
\hline
\end{tabular}

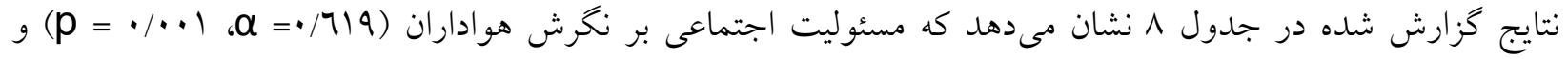

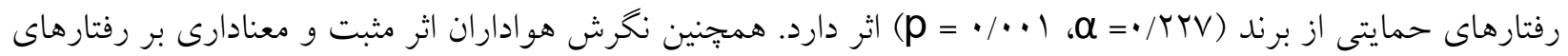
حمايتى از برند (TYT/

علاوه بر اين براين بررسى نقش ميانجى نخرش هواداران مشخص كرديد كه مسئوليت اجتماعى بر رفتارهاى حمايتى از

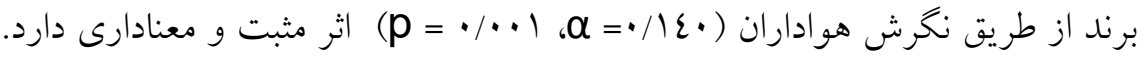




\section{بزوهش در مديريت ورزشى و رفتار حركتى - دوره يازهمر ، شمارهبr، +. ع|}

همجنين نتايج حاصل از تحليل اثر متقابلع (در حالتى كه متغير تعديلكر بيوسته است از از معادله براى تبيين نقش متغير تعديل گر استفاده مىشود، با استناد به اين معادله از حاصل - Y=i+b ضرب متغير تعديلگر (ادر اين تحقيق مسئوليتيذيرى اجتماعى)" و متغير مستقل (ادر اين تحقيق همدلى") و افزودن آن به مدل معادلات ساختارى نقش تعديلگر مسئوليت يذيرى اجتماعى در ارتباط بين همدلى و رفتارهاى حمايتى از برند، ارزيابى مى شود) نشان داد كه همدلى در ارتباط بين مسئوليت يذيرى اجتماعى و رفتارهاى حمايتى از برند هواداران نقش

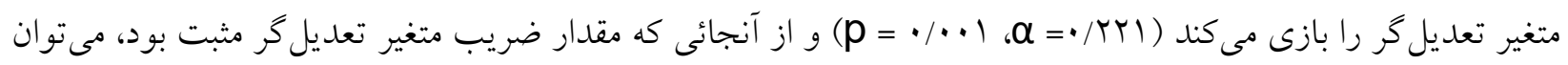
اشاره به اين داشت كه با افزايش همدلى رابطه بين مسئوليتيذيرى اجتماعى و رفتارهاى حمايتى از برند تقويت مىشود.

\section{بحث و نتيجه تيرى}

مســوليت اجتماعى امرى حياتى و ضـامن بقاى ســازمانها در جوامع امروزى اسـتـ. در اين ميان، طبق نتايج حاصـل هواداران نيز رعايت بعد اخلاقى باشگاه را مهمتر از ساير ابعاد تلقى كردهاند. زيرا باشخاههاى ورز شى كه نوعى سازمان ورزشى محسوب مىشوند، الكوى اخلاقى بسيار مهمى در جامعهاند. بنابراين، انتظار ميرود فعاليتهايشان مطابق با اصول اخلاقى، ارزشىها و هنجارهاى مورد قبول جامعه باشد. به طورى كه اخر هو اداران از رفتار بازيكنان و مربيان محبوبـشئان موارد مغاير با جوانمردى و ا صول اخلاقى را الخوبردارى كنند، با شگاه مـ سئول گ گسترش بىاخلاقى در جامعه ا ست؛ و حتى در برخى موارد موجب محروميت بازيكنان، مربيان و هواداران حاضـر در ورزشـعاه خواهد شـد. در رابطه با نتايج

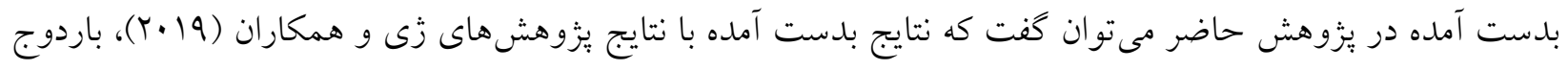

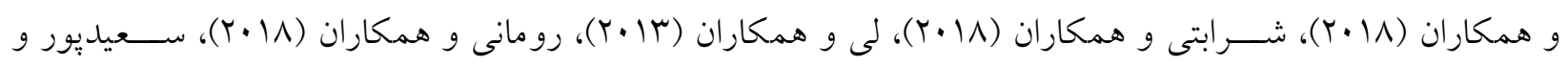

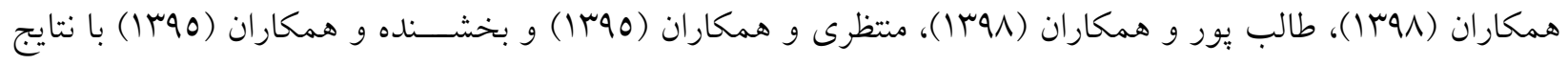

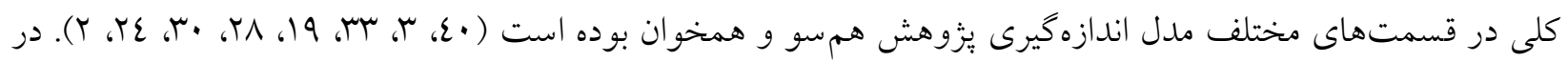
اين مطالعهى حاضر به بررسى حوزهى حمايت مصرف كننده در ياسخ به اقدامات مسئوليت اجتماعى مسئولانهى سازمان

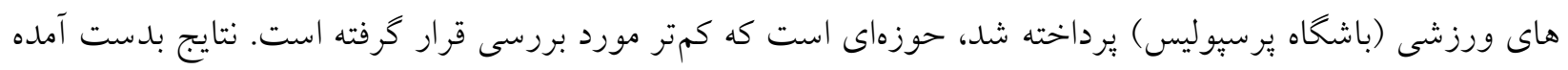

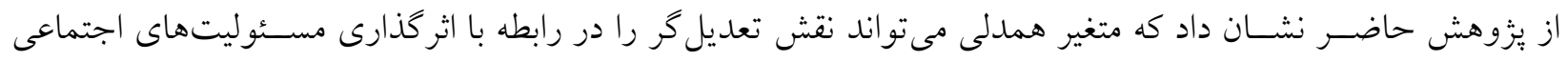
باشخاه بر رفتارهاى حمايتى هواداران داشته باشد. در اين رابطه مىتوان كفت باشـحاه يرسـيوليس به عنوان يكى از يرطرفدارترين تيمهاى ورزشسى در ايران و حتى آسـيا

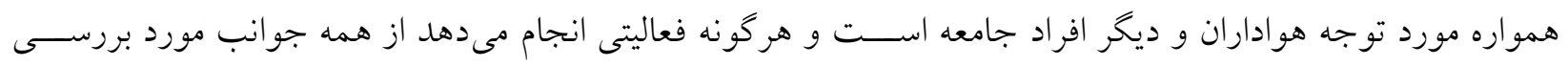
هواداران قرار خواهد گرفت، و با توجه به عمل انجام شـده بازخوردهاى آن نيز توسطط هواداران به باشـعاه ارائه خواهد شـــ از اين رو بنا بر به نتيجه بدسـت آمده مىتوان بيان كرد، براى اينكه هواداران رفتارهاى حمايتى بيشـترى از باشـعاه

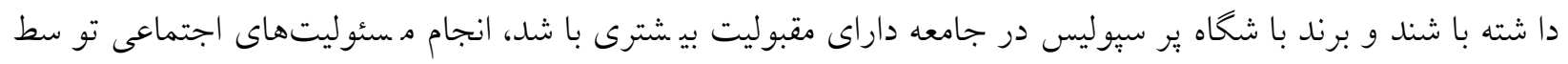

\footnotetext{
${ }^{4}$ Interaction
} 


\section{بزوهش در مديريت ورزشى و رفتار حركتى - دوره يازهمر ، شمارهبr، +. ع|}

باشــاه، يكى از موارد مهمى اســت كه بايد به آن توجه شــود و در اين راســتا با توجه به توان و ظرفيتى كه دارد با برنامهريزى مناسب از سوى مسئولين مىتواند به شكل بسيار منا سبى اين امر مهم را انجام دهد. در اين راستا از جمله مســئوليتهاى كه مىتواند انجام دهد، تشــكيل آكادمى هاى فوتبال رايخان براى كودكان و نوجوانان در مناطق محروم

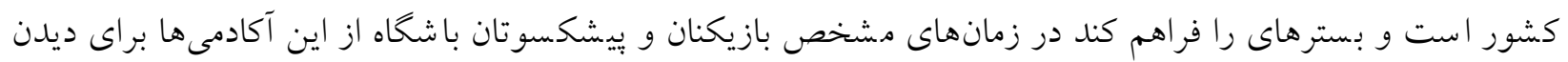

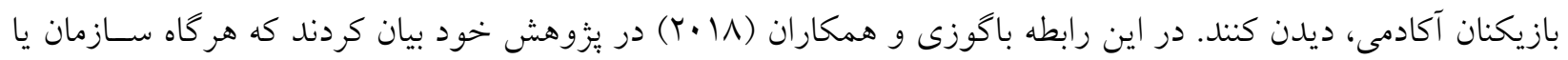

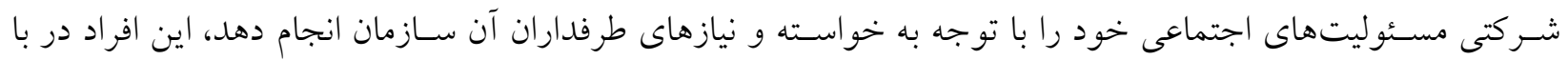
همدلى مثبت در اجراى فعاليتهاى ياد شده سازمان يا شركت همر اهى مى كنند و از طريق تبليغات دهان به دهان نيز كه يكى از مولفه هاى رفتارهاى حمايتى است حمايت خود را اعلام مى كنند. منطق معقول آن است كه همدلى احساس شمده، حالات خو شايندى هستند و به مصرف كنند گان (هوادار) انخيزه داده مى شود كه خوشى خود را به اشتراك بخذارند و به سازمانهاى قابل تحسين واكنش مثبتى نشان دهند تا گسترش بيابند و بر احساسات خوبشان تكيه كنند و احساس رفاه افراد را حفظ نموده يا حتى افزايش دهند. استدلال مشابهى در روانشناسى يايه بهكار برده شده است (Y). هرجند از يك

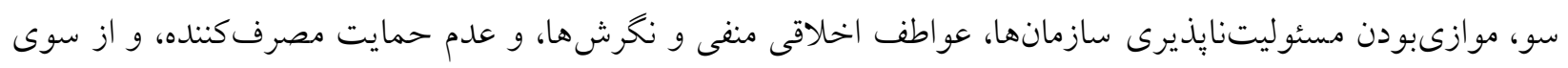
ديخر، هـ سئوليتيذيرى اجتماعى سازمانها، احسا سات اخلاقى مثبت و نحرش ها، و حمايت مصرف كننده ممكن ا ست طبيعى و حتى روشن به نظر بر سند، اما ادبيات روان شناسى بيان مى كند كه عواطف منفى و مثبت، درجهى معينى از عدم

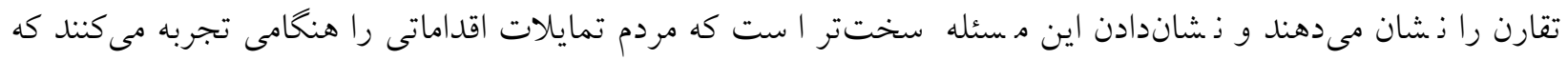

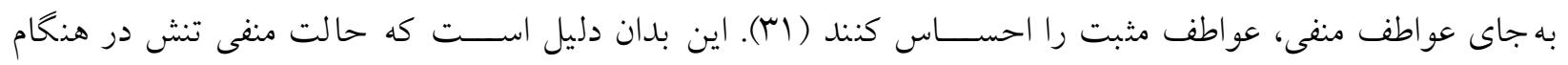
تجربهكردن عو اطف منفى، تعادل فرد را برهم مىزند و بايد كارى براى بازيابى تعادل انجام شود. اما هنگامى كه احساس

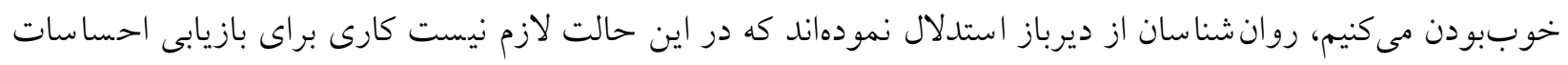

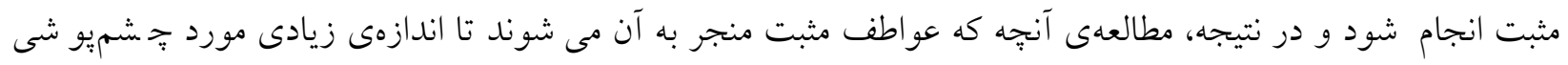

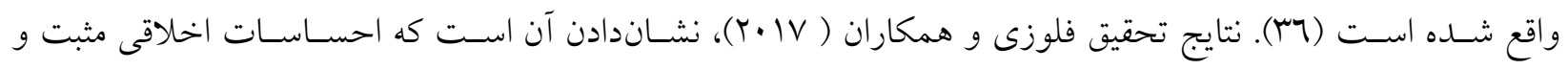

نخرشها، مصرف كنند كان را بهسمت واكنش به رفتارهاى خوبى مىبرد كه توسط سازمانها انجام شده است (N). همدلى نسـبت به رويههاى عملى مسـئوليتهاى اجتماعى، اقدامات را براى حمايت از شـركتهاى داراى رفتار خوب برمى انخَيزاند. همدلى هوادار، احساساتى خوشايند هستند و معمولاً همانند عواطف منفى كه ناخوشايند و ناهنجار هستند سبب ايجاد نيازى ضرورى براى كنار آمدن با جنين احساساتى نمىشوند. با اين حال، تحقيقات روانشناسى نشان مىدهد كه قدردانى افراد را به دركيرى با رفتار جامعهيار (جامعهِيسند) با افرادى سوق مى دهد كه در حق آنان نيكو كارى كردهاند

براى همدل بودن هوادار با باشـعاه يرسـيوليس، لازم اسـت باشـعاه در انجام فعاليتهاى خود در راسـتاى مسـئوليت اجتماعى، از هواداران نيز كمك بخيرد و هواداران را نيز دركير كند و حتى در صورت امكان نيز بخشى از اين فعاليتهارا به خود هواداران واكذار نمايد، تا همدلى مناسبى بين باشگاه و هواداران و حتى جامعه برقرار شود. 


\section{بزوهش در مديريت ورزشى و رفتار حركتى - دوره يازهمر ، شمارهبr، +. ع|}

ديد كاه هواداران در با شگاهها بخ صوص با شگاه بر سبوليس ذ سبت به ابعاد مـ سئوليت اجتماعى مىتواند حاوى نتايج و نكات مهمى براى مديران و بازريابان ورزشى باشد، بهطورى كه بازاريابان و مديران تيمهاى ورزشى مىتواند با توجه به اين ديد گاهها و حسا سيتهاى هواداران نسبت به مسائل اجتماعى، طرحها و برنامههاى هسئوليت اجتماعى خود را اجرا كنند و يا بهبود بخششند. بنابر اين در مورد نمايش اقدامات مـسئوليتهاى اجتماعى، مصرف كنند كان بايد با احساس كردن يك نياز مبرم به باداشدادن به شركتى با رفتار خوب، به قدردانى احساس شده يا سخ دهند و بايد با تمايل به ذشاندادن

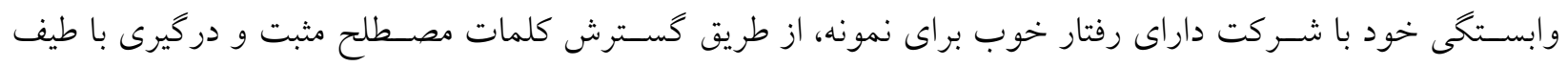
و سيعى از رفتارهاى حمايتى ذسبت به برند باشگاه، به برافراشتكى احساس شده يا سخ دهند (وس). همجنين با توجه به

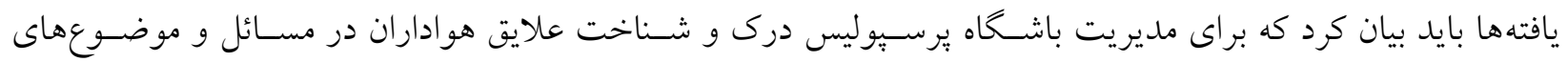
اجتماعى و نيز واكنش هواداران به برنامههاى مختلف هـئوليت اجتماعى بـسيار مهم است. مجموعه با شخاه ير سبوليس بايد در نظر داشته باشند كه مسئوليت اجتماعى داراى اثرى مثبت بطور مستقيم و غيره مستقيم بر ذهن و نخرش هو اداران است. يافتن روشها و تاكتيكهاى بازاريابى مسئوليت اجتماعى از ميان گزينهاى مختلف و گوناكون مانند حمايت مالى از رويدادها، تاسيس يا كسترش سازمانهاى خيريه، تشويق هواداران براى صرفهجويى در مصرف انرزى، داراى اهميت بسيارى است. علاوه براين مسئولين باشخاه بر سيوليس بايد بر ترويج و برقرارى ارتباط با هواداران خارج از كشور نيز فعاليت هاى مثبى در راستاى مسئوليت اجتماعى باشگاه انجام دهند. بر اساس نتايج تحقيق حاضر و تحقيقات مشابه به نظر مير سد برداختن به فعاليتهاى م. سئوليت اجتماعى تو سط با شخاهها تأثير مثبت و م. ستقيم بر رفتارهاى حمايتى از با شگاهها دارد. رابطه بين رفتارهاى حمايتى و حفظ برترى رقابتى به طور و سيع در ادبيات تأييد شده ا ست. رفتارهاى حمايتى به طور مـ ستدل با ارزشترين سرمايه سازمان ا ست. رفتارهاى حمايتى مىتواند منجر به سودهاى ا ستراتزيك بسـيارى از جمله كاهش هزينهها شــود. رفتارهاى حمايتى بالا احتمال اينكه يكى سـهامدار با شــركت قرارداد ببندد را افزايش مىدهد. رفتارهاى حمايتى شـــركت يكى فاكتور حياتى براى موفقيت اســت و مىتواند يكى از با ارزشترين سـرمايههاى ناملموس در دسـترس شـركت باشـــ (Y) (I). رفتارهاى حمايتى يكى شـركت يكى منبع مزيت رقابتى براى شـركتها اسـتـ. در بسـيارى از موارد رفتارهاى حمايتى مثبت مىتواند از افزايش قيمت حمايت كند. با در نظر كرفتن با شخاه فوتبال به عنوان يكى سازمان ورز شى، اين مزيتها در قالب افزايش ميزان سرمايه كذارى حاميان مالى و افزايش سود سهام باشگاه، افزايش محبوبيت بازيكنان باشگاه و به طبع آن افزايش مبلغ فروش بازيكن به ساير باشكاهها، افزايش تما شاجيان حا ضر در در ورز شخاه و كاهش مقاومت به قيمت بليت مسابقات از بيامدهاى رفتارهاى حمايتى مىبا شند. همجنين يّ شنهاد مى شود تيمهاى ورز شى كه خواهان ايجاد حمايت هـ ستند، بر طرحهاى هـ سئوليت اجتماعى همراه با راهبردهاى بازاريابى، با هدف بهبود نخرش هواداران به تيم خود و ايجاد احسـاس اخلاقى مثبت در هواداران نسـبت به

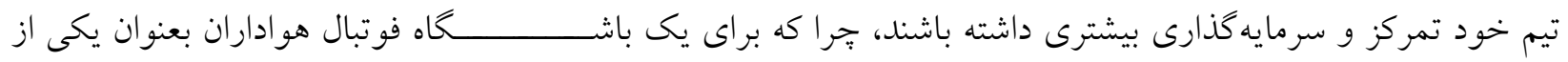
كروههاى ذينفع هميشــه مورد توجه قرار گرفتهاند (11). همجنين با توجه به اهميت نحرش هواداران در باشـــاههاى فوتبال در ايران بهخصوص با شگاههاى برطرفدار مانند بر سبوليس ذسبت به رعايت برخى شاخص هاى اخلاقى در اين 
باشكاهها از جمله عدم تبعيض نزادى در قبال بازيكنان و هواداران، عدم تبعيض جنس ـ-- سيتى در قبال هواداران و اهميت

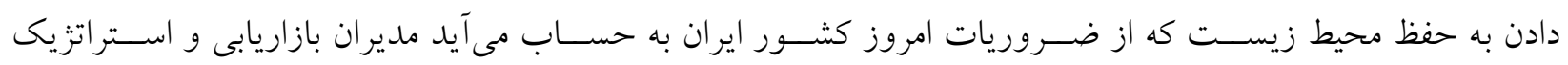
باشــاههاى فوتبال را نســبت به برنامهريزى براى رعايت شــاخصهاى اخلاقى در باشـــاههاى فوتبال توجيه كند تا

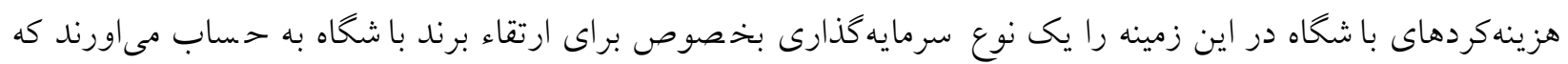
در نهايت منجر به رفتارهاى حمايتى از سـوى هوادران شـود. در نهايت بايد بيان كرد مســوليت اجتماعى يكى موضسوع اقتصادى، اخلاقى، قانونى، بشردو ستانه و زيست محيطى است كه مديران باشگاه يُ سبوليس بايد آن را دنبال كنند، جهون مسئوليت اجتماعى به يكى ابزار اصلى در بازاريابى تبديل شده است و اخر باشخاه اقدامهاى مسئوليت اجتماعى را ناديده

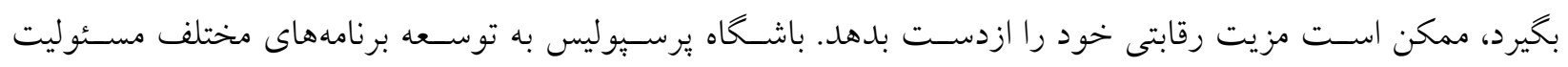
اجتماعى با محوريت هوادارن احتياج دارد، و با ارائه اين برنامههاى در خصسوص مسـئوليت اجتماعى، مديران ورزشسى باشخاه علاوه بر تصاحب قلب هواداران، به اهداف مالى خود نيز دست مىيابند. در بايان بايد گفت هر يزوهـشى داراى محدويتهاى ا ست، از جمله محدوديتهاى يزوهش حا ضر مىتوان به تعميم دادن نتايج يزوهش ا شاره كرد، كه نتايج

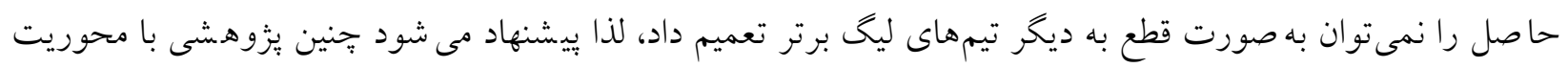

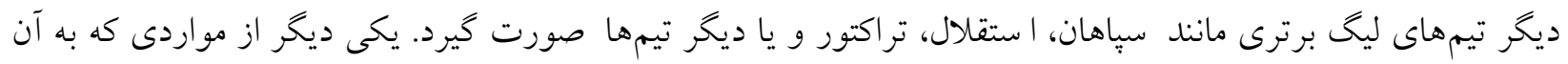

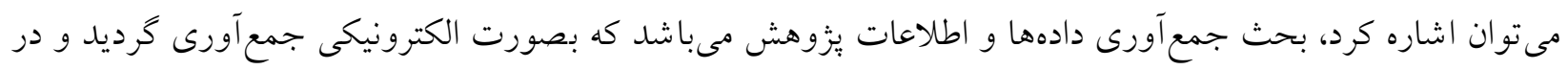

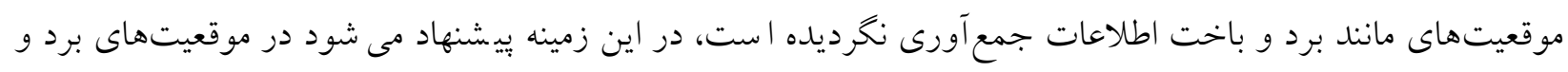
باخت، رفتارهاى حمايتى از باشخاه از سوى هواداران مورد سنجش قرار گيرد.

\section{References}

1. Adams A, Armitage S. Mutuality for football clubs? Lessons from the financial sector. Studies in Economics and Finance.2014, Jan 1;22(1):26-41.

2. Bakhshandeh, Hossein, Jalali Farahani, Majid, Sajjadi, Seyed Nasrollah. The effect of social responsibility on the prestige of selected teams in the Iranian Football League. Applied Research in Organizational Behavior Management.2018. (Persian).

3. Bhaedroch, C. B., \& Sen, S. Consumer-company identification: A framework for understanding consumers' relationships with companies. Journal of Marketing.2018, 67(2), 76-88.

4. Brown, T. J., \& Dacin, P. A. The company and the product: Corporate associations and consumer product responses. Journal of Marketing.1997, 61(1), 68-84.

5. Brunk, K. H. Un/ethical company and brand perceptions: Conceptualising and operationalising consumer meanings. Journal of business ethics. 2018, 111(4), 551-565.

6. Davari, Ali; Rezazadeh, Arash. Structural Equation Modeling with PLS Software, Second Edition, Tehran: Jihad Daneshgahi Publishing Organization.2017. (Persian).

7. Delaware, Ali. Probability and Applied Statistics in Psychology and Educational Sciences. Ninth Edition, Tehran: Roshan Publications.2010. (Persian). 
8. Filizöz, B., \& Fişne, M. Corporate social responsibility: A study of striking corporate social responsibility practices in sport management. Procedia Social and Behavioral Sciences.2017, 24, 1405-17.

9. Fornell, C., \& Larcker, D. F. Evaluating structural equation models with unobservable variables and measurement error, Journal of marketing research.2008, 18(1). 39-50.

10. Galbreath J. How does corporate social responsibility benefit firms? Evidence from Australia. European Business Review. 2010, Jun 29;22(4):411-31

11. Ghanbari, Jamshid, Eskandari Ulfat, Saed Atai Fardin. The effect of practical team leadership on team performance through team learning and satisfaction mediation. Organizational Behavioral Studies.2017, 5 (4): 21-45. (Persian).

12. Giroux, M., Pons, F., \& Mourali, M. Is CSR important for all types of fans?:The value of corporate social responsibility in sport. In J. L. Robinson (ed.),Marketing dynamism \& sustainability: Things change, things stay the same:Proceedings of the 2012 academy of marketing science (AMS) annual conference(497-500). Book Section, Cham: Springer International Publishing.2015.

13. Hair Jr JF, Hult GT, Ringle C, Sarstedt M. A primer on partial least squares structural equation modeling (PLS-SEM). Sage Publications. Second Edition.2016.

14. Henseler, J; Ringle, C. M; \& Sinkovics, R. R. The use of partial least squares path modeling in international marketing. In New challenges to international marketing. Emerald Group Publishing Limited.2009, 5 (28) :21-33.

15. Irshad A, Rahim A, Khan MF, Khan MM. The impact of corporate social responsibility on customer satisfaction and customer loyalty, moderating effect of corporate image. City University Research Journal.; 1:63-73.

16. Kline, P. An easy guide to factor analysis. Routledge, Bioscience Biotechnology Research Communications.2014, 10(4). 746-751.

17. Kumar, V., \& Reinartz, W. Creating enduring customer value. Journal of Marketing. 2016, 80(6), 36-68.

18. Lazarus, R. S. Emotion and adaptation. New York, NY: Oxford University Press.1991.

19. Lee S, Singal M, Kang KH. The corporate social responsibility-financial performance link in the US restaurant industry: do economic conditions matter? International Journal of Hospitality Management.2013, Mar 1; 32:2-10

20. Losoya, S. H., \& Eisenberg, N. Affective empathy. In J. A. Hall, \& F. J. Bernieri (Eds.). Theory and measurement. 2001, pp. 21-43. Mahwah, NJ: Erlbaum

21. Malhotra, N. K., \& Agarwal, J. Ethics and morality in consumer-brand relationships.2017. (Call for a special issue in Journal of Business Research).

22. McCullough, M. E., Kimeldorf, M. B., \& Cohen, A. D. An adaptation for altruism? The social causes, social effects and social evolution of gratitude. Current Directions in Psychological Science.2008, 17, 281-285.

23. Montazeri, Amir, Talibpour, Mehdi, Andam, Reza, Kazemnejad, Anoushirvan. The role of social responsibilities in the attitude of Iranian football fans. Sports Management Studies.2019, 11 (53): 157-180DOI: 10.22089 / smrj.2017.3982.1769. (Persian).

24. Montazeri, Amir, Talibpour, Mehdi, Andam, Reza, Kazemnejad, Anoushirvan. Measuring Corporate Social Responsibility in the Sports Industry: Development and Validation of the Applied Sports Science Yearbook Measurement Scale.2016, 5 (2), 97-114. (Persian). 
25. Mueller, R. O. Basic principles of structural equation modeling: An introduction to LISREL and EQS. Springer Science \& Business Media.1999.

26. Murphy, L. \& Wood. An ethical basis for relationship marketing: A virtue ethics perspective. European Journal of Marketing.2007, 41(1/2), 37-57.

27. Nami, Ahmad, Gholampour, Ali. Investigating the factor structure of social responsibility, customer satisfaction, organizational credibility and performance in companies (Case study: Shahr Bank).2016, IUESA 5 (17): 1-12. (Persian).

28. Romani, S., Grappi, S., \& Bagozzi, R. P. Corporate socially responsible initiatives and their effects on consumption of green products. Journal of Business Ethics.2016, 135(2), 253264

29. Romani, S., Grappi, S., \& Bagozzi, R. P. Corporate socially responsible initiatives and their effects on consumption of green products. Journal of Business Ethics.2018, 135(2), 253264

30. Saeedpour, Samaneh, Aghaei, Najaf, Elahi, Ali Reza. The role of social responsibility in the performance of Persepolis club team through the technique of satisfaction. Journal of Organizational Behavior Studies in Sport. 2019, 6, 1, pp. 11-195. (Persian).

31. Sen, S., Du, S., \& Bhattacharya, C. B. Corporate social responsibility: A consumer psychology perspective. Current Opinion in Psychology.2016 10, 70-75.

32. Sen, S., Du, S., \& Bhattacharya, C. B. Corporate social responsibility: A consumer psychology perspective. Current Opinion in Psychology.2016, 10, 70-75.

33. Sharabati AA. Effect of corporate social responsibility on Jordan pharmaceutical industry's business performance. Social Responsibility Journal.2018, Aug 6;14(3):566-83.

34. Solomon MR, Marshall GW, Stuart EW. Marketing:Real People, Real Choice $.7^{\text {th }}$ ed. New Jersey: Prentice Hall; 2011.

35. Tenenhaus, M; Amato, S; \& Esposito Vinzi, V. A global goodness-of-fit index for PLS structural equation modelling. In Proceedings of the XLII SIS scientific meeting.2004, 1. 739742.

36. Vitell, S. J., King, R. A., Howie, K., Toti, J. F., Albert, L., Hidalgo, E. R., \& Yacout, O. Spirituality, moral identity, and consumer ethics: A multi-cultural study. Journal of Business Ethics.2016, 139(1), 147-160.

37. Walker, M. B., \& Kent, A. Research and Reviews Do Fans Care? Assessing the Influence of Corporate Social Responsibility on Consumer Attitudes in the Sport Industry

38. Wetzels, M; Odekerken-Schröder, G; \& Van Oppen, C. Using PLS path modeling for assessing hierarchical construct models: Guidelines and empirical illustration. MIS quarterly. 2009, 177-195.

39. Xie, C., Bagozzi, R. P., \& Grønhaug, K. The role of moral emotions and individual differences in consumer responses to corporate green and non-green actions. Journal of the Academy of Marketing Science.2015, 43, 333-356.

40. Xie, C., Bagozzi, R. P., \& Grønhaug, K. The impact of corporate social responsibility on consumer brand advocacy:The role of moral emotions, attitudes, and individual differences. Journal of Business Research.2019, 62(3), 267-275. 